Old Dominion University

ODU Digital Commons

Civil \& Environmental Engineering Theses \&

Dissertations

Civil \& Environmental Engineering

Fall 2015

\title{
Techno-Economic Analysis of Protein Concentrate Produced by Flash Hydrolysis of Microalgae
}

Alexander Nana Yaw Asiedu

Old Dominion University, aasie001@odu.edu

Follow this and additional works at: https://digitalcommons.odu.edu/cee_etds

Part of the Economics Commons, and the Environmental Engineering Commons

\section{Recommended Citation}

Asiedu, Alexander N.. "Techno-Economic Analysis of Protein Concentrate Produced by Flash Hydrolysis of Microalgae" (2015). Master of Science (MS), Thesis, Civil \& Environmental Engineering, Old Dominion University, DOI: 10.25777/tjyb-xv07

https://digitalcommons.odu.edu/cee_etds/3

This Thesis is brought to you for free and open access by the Civil \& Environmental Engineering at ODU Digital Commons. It has been accepted for inclusion in Civil \& Environmental Engineering Theses \& Dissertations by an authorized administrator of ODU Digital Commons. For more information, please contact digitalcommons@odu.edu. 
TECHNO-ECONOMIC ANALYSIS OF PROTEIN CONCENTRATE

PRODUCED BY FLASH HYDROLYSIS OF MICROALGAE

by

Alexander Asiedu

BSc. March 2003, Kwame Nkrumah University of Science and

Technology, Ghana

MSc. June 2008, Kwame Nkrumah University of Science and

Technology, Ghana

Thesis Submitted to the Faculty of Old Dominion University in Partial Fulfillment of the Requirements for the Degree of

\author{
MASTER OF SCIENCE \\ ENVIRONMENTAL ENGINEERING \\ OLD DOMINION UNIVERSITY
}

December 2015

Approved by:

Sandeep Kumar (Director)

Ben J Stuart (Member)

Mujde Erten-Unal (Member) 


\title{
ABSTRACT \\ TECHNO-ECONOMIC ANALYSIS OF PROTEIN CONCENTRATE PRODUCED \\ BY FLASH HYDROLYSIS OF MICROALGAE
}

\author{
Alexander Asiedu \\ Old Dominion University, 2015 \\ Director: Sandeep Kumar
}

Process simulation and techno-economic analysis of 95wt.\% protein concentrate from microalgae has been performed using SuperPro Designer v. 9.0. This work, first of its kind, is focused on the economic analysis of protein concentrate that includes processes such as microalgae cultivation, harvesting, protein extraction and drying steps. A baseline capacity of 160 MT/day protein concentrate production on commercial basis has been analyzed. This throughput requires 336 MT/day dry algae (54 wt.\% protein). The amount of carbon dioxide required to grow this quantum of algae is estimated to be $648 \mathrm{MT} /$ day, which is produced from an in situ $21 \mathrm{MW}$ power plant run by approximately $12 \mathrm{MT} / \mathrm{h}$ natural gas (methane).

The economic feasibility study has been performed for the entire process. It became clear that decreasing the amount of water of the microalgae biomass slurry to the flash hydrolyzer reduces the fixed capital investment (FCI) and the annual operating cost (AOC). The baseline production of protein concentrate reveals the following results: FCI: \$264 million; AOC: \$145 million; capital recovery: \$180 million/year for 15 years; unit cost of production: $\$ 2.86 / \mathrm{kg}$ protein depending on the algae slurry density; minimum selling price: \$4.13/kg protein; power requirement: 19.5 MW; Land requirement: 7177 acres; water: 15576 MT/day (4.1MGD). 
Further analysis revealed that the major contributors to the financial statue of this work is contingent on the algae slurry going to the flash hydrolysis, protein content of the microalgae, pond depth for algae cultivation, and algae productivity. 


\section{ACKNOWLEDGMENT}

I am highly indebted to committee members for their unlimited patience, hours of guidance and invaluable critiques toward this thesis. Moreover, the untiring efforts of my advisor deserves special recognition.

This work was supported by the National Science Foundation (NSF). 


\section{NOMENCLATURE}

\begin{tabular}{|c|c|}
\hline AFC & Annualized Fixed Cost \\
\hline $\mathrm{AOC}$ & Annual Operating Cost \\
\hline DC & Direct Cost \\
\hline DCF ROI & Discounted Cash Flow Return on Investment \\
\hline DO & Dissolved Oxygen \\
\hline FCI & Fixed Capital Investment \\
\hline FC & Fixed Capital \\
\hline FH & Flash Hydrolysis \\
\hline IC & Indirect Cost \\
\hline IRR & Internal Rate of Return \\
\hline MEA & Monoethanolamine \\
\hline NPV & Net Present Value \\
\hline $\mathrm{OC}$ & Other Cost \\
\hline PAR & Active Radiation \\
\hline PB & Payback Period \\
\hline PBR & Closed Photobioreactors \\
\hline PC & Purchase Cost \\
\hline $\mathrm{PE}$ & Photosynthetic Efficiency \\
\hline ROI & Return on Investment \\
\hline TAC & Total Annualized Cost \\
\hline TCI & Total Capital Investment \\
\hline
\end{tabular}




\section{TABLE OF CONTENTS}

Page

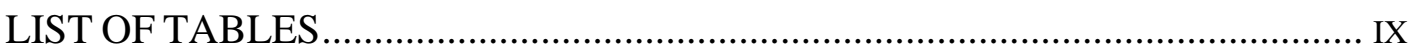

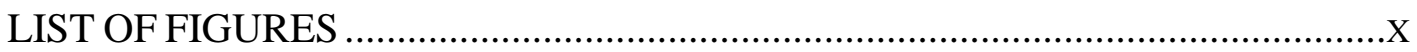

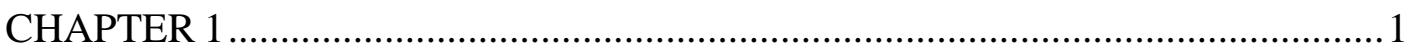

1.1 BACKGROUND AND JUSTIFICATION............................................1

1.2 RESEARCH AIMS AND OBJECTIVES ...............................................4

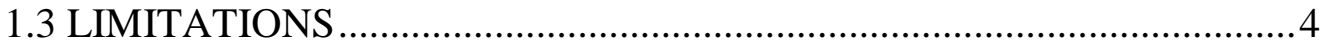

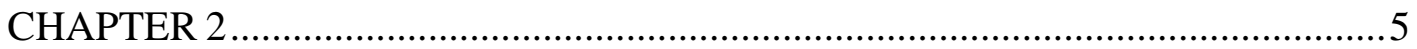

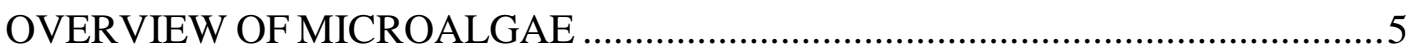

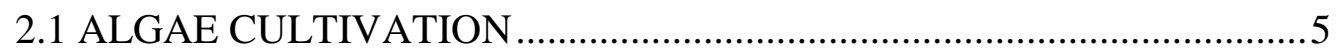

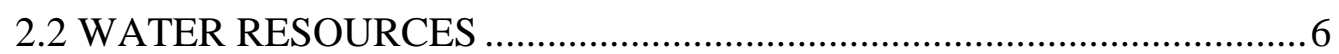

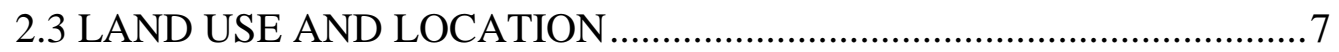

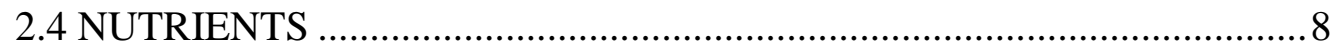

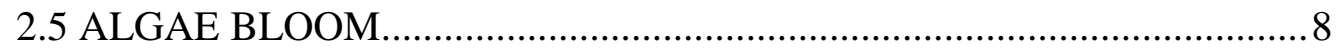

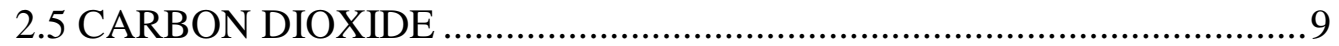

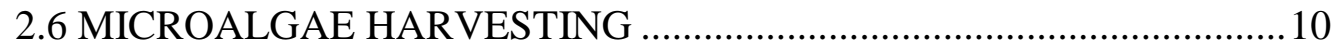

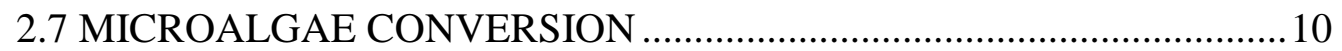

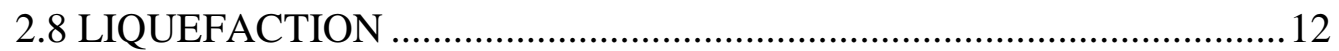

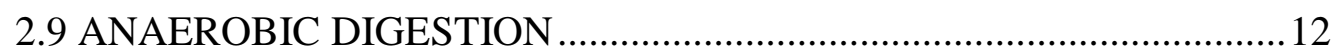

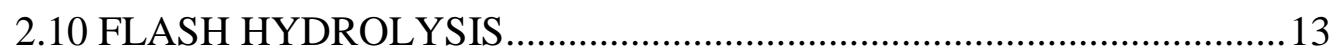

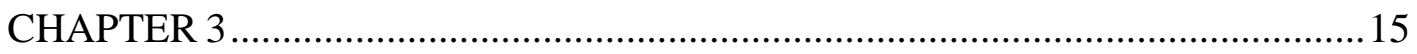


CHAPTER 4

SIMULATIONS

4.1 PROCESS MODELLING

4.2 ESSENTIAL ASSUMPTIONS

4.3 PROCESS DESCRIPTION

4.4 ECONOMIC ANALYSIS

CHAPTER 5 .25

RESULTS AND DISCUSSIONS

5.1 SENSITIVITY ANALYSIS

5.2 EFFECT OF FLASH HYDROLYSIS PERCENT CONVERSION

5.4 EFFECT OF PROTEIN CONTENT IN THE ALGAE .31

5.5 EFFECT OF ALGAE PRODUCTIVITY

5.6 EFFECT OF WATER RECYCLE.

5.7 EFFECT OF ALGAE SLURRY

5.8 EFFECT OF PROJECT LIFE. 


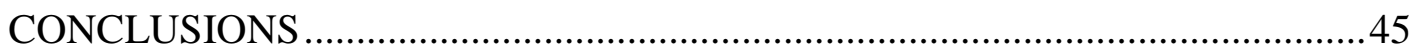

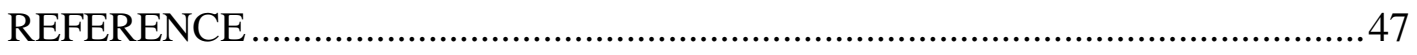

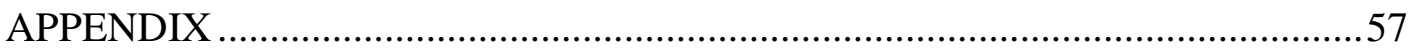

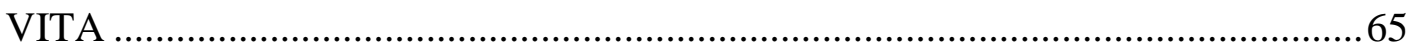




\section{LIST OF TABLES}

Table

Page

1 General Composition of Different Algae (\% of dry matter)..............................3

1.1 General Productivity of different microalgae .................................................

3 Algal culture systems, types, yields, and cost of production estimates............... 5

4 Solar irradiation data for different locations ................................................. 7

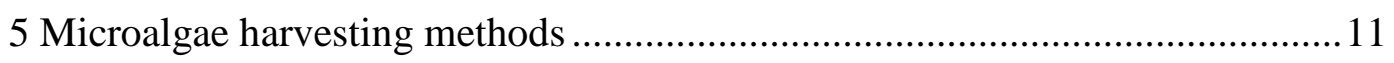

6 Capital Cost estimation for 160 MT/day protein concentrate...........................23

7 Annual Operating Cost for 160 MT/day Protein Concentrate ............................24

8 Energy consumption at the various sections .................................................28

9 Revenue/Credit Summary for 160 MT/day of Protein Concentrate ....................28

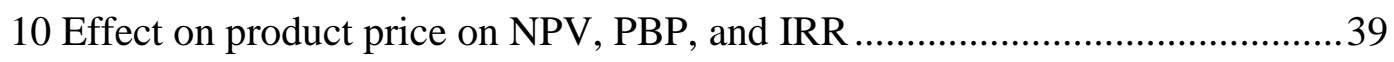

A1 Calculation of minimum protein concentrate.............................................59

A2 Simulation based on production of different capacities..................................60

A3. Prices of Protein Concentrates on the market ................................................63 


\section{LIST OF FIGURES}

Figure

1 Reaction network for the HTL of Nannochloropsis sp...................................14

2 Simplified Process flowsheet for protein concentrate production. ....................21

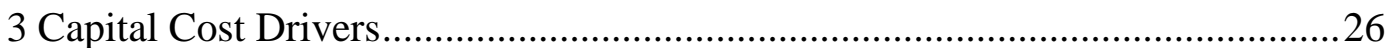

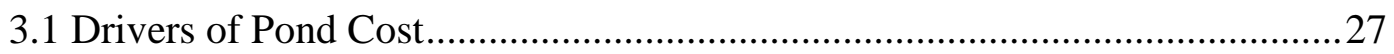

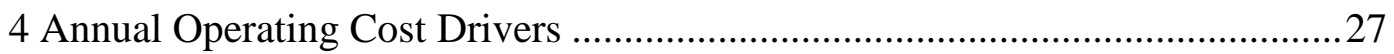

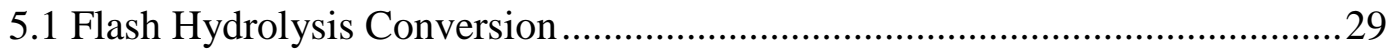

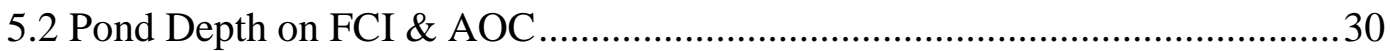

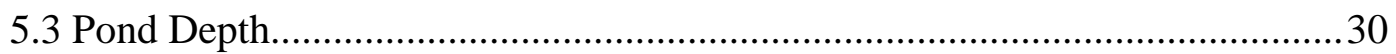

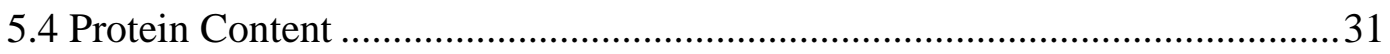

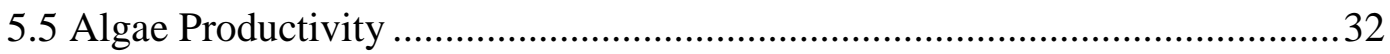

5.6 Water Recycle and Total Water Used..........................................................33

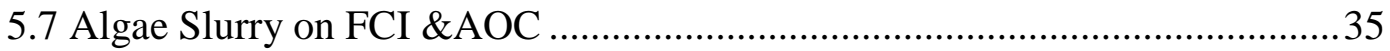

5.8 Algae Slurry on Minimum Price-Unit Cost ......................................................35

5.9 Project life Product Minimum Price ...............................................................36

5.10 Project Life on Annualized Cost................................................................37

5.11 Discount rate on minimum Product price .....................................................37

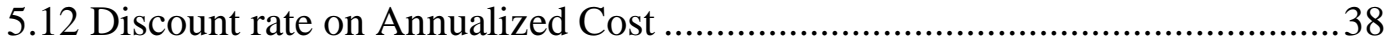

5.13 Product Price on PBP \& Discount Rate ..........................................................39

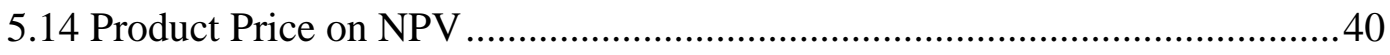

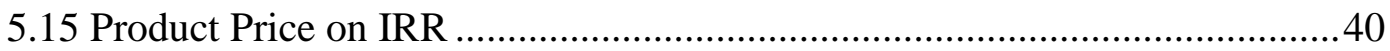

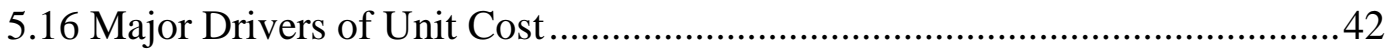

5.17 Major Drivers of the Protein Price...............................................................43

5.18 Production Capacity against Unit Cost \&Price.............................................44 
5.19 Production Capacity against FCI \& AOC .................................................44

A1 Production of protein concentrate via F.H. ...............................................64 


\section{CHAPTER 1}

\subsection{Background and Justification}

Microalgae research has been in the forefront of the energy research since the inception of fossil-fuel-depletion awareness. This particular biological entity has received attention because of its high levels of oil, protein and carbohydrate. Moreover, it has remarkable potential utilization of poor quality land and water, and acts as a deep sink for carbon dioxide from energy-producing sector such as coal-fired power plants [Quinn et al., 2014].

Besides its high energy content, microalgae, which are classified as heterogeneous organisms possess both food and biological ingredients. Phaeophyceae are well-known for having an important class of phenolic compounds and phlorotannins, which are strong sources of bioactivities including antioxidant, antiinflammatory, antidiabetic, anti-proliferative or antibacterial effects [SánchezCamargo et al., 2015].

Scenedesmus obliquus, another kind microalgae, contains considerable level of astaxanthin (3, 30-dihydroxy-b, $\beta$-carotene-4, 40-dione) that is a natural ketocarotenoid pigment which has been widely used in feed as colorant. It has superior antioxidative activity, potential inhibitory action to the proliferation of some cancer cells and correlation with the enhancement of T-cell activity in human [Qin et al, 2008]. Tibbetts et al. reported a general composition of microalgae: ash (5-17\%), moderate to high carbohydrate (18-46 \%), crude protein (18- $46 \%$ ), high crude lipid (12- $48 \%$ ), and

energy (19-27 $\mathrm{MJ} \mathrm{kg}^{-1}$ ). Other reporters quoted that microalgae has high protein content of 39-71\% dry mater; pigments, and other bioactive constituents like dietary fibres (as high as $74.6 \%$ on dry basis) in some species; carotenoids, carbohydrates, 
omega-3 fatty acids, which have tremendous use in the pharmaceutical industries [Balasubramanian et al., 2011]. Furthermore, Chlorella vulgaris has been reported to have the following essential amino acid (\%wt), the framework of proteins: aspartic acid 8.6, threonine 5.5, serine 4.4, glutamic acid 10.3, proline 5.0, glycine 7.0, alanine 10.7, valine 6.7 , methionine 2.6, cysteine 1.3 , isoleucine 3.4 , leucine 8.2 , tyrosine 4.4 , phenylalanine 6.0, histidine 1.6, lysine 5.4, arginine 7.4, tryptophan 0.2, ammonia 1.3 [Ursu et al., 2014]. Table 1 highlights composition of different species of microalgae. Generally, the high contents of proteins in microalgae have undoubtedly proven that it is a prominent candidate for the production of peptide or protein concentrate for both food and pharmaceutical industries apart from being bioenergy source.

Despite the immense bioactive components in the algae, less research has gone into extracting these component. To extract these essential components, for example, protein, the cell wall of the algae needs to be breached. Because of this, bead milling [Doucha et al. 2008, \& Lee et la. 2011], ultrasonication [Furuki et al.2003, Gouveia et al. 2009, Gerde et al.2012], microwave radiation [Zheng, et al. 2011], enzymatic treatment [Fleurence et al. 1999, Sari et al. 2013], cell homogenizer [Mendes-Pinto et al. 2001] and high-pressure cell disruption [Jubeau et al. 2012] have been reported.

However, all these methods are tedious and time consuming. Garcia-Moscoso et al. reported of protein extraction from microalgae via flash hydrolysis (FH) at the laboratory level. This method proved to be most efficient in extracting the protein from the microalgae in 10 seconds. Flash hydrolysis in subcritical water (below $374^{\circ} \mathrm{C}$ and 22.1 MPa) extracted proteins efficiently and produced lipid-rich biofuel intermediates from wet microalgae (Scenedesmus sp.) in a continuous flow process. However, there has been no studies related to techno-economic analysis of protein extraction. 
In this study, the results from the laboratory level studies were used to develop a techno-economic analysis of FH process when Scenedesmus obliquus (17 \% lipid, 23 \% Carbohydrate, and 54\% protein) was used as a feedstock. Flash hydrolysis is carried out in a subcritical water at temperature below $374^{\circ} \mathrm{C}$ and pressure $22.1 \mathrm{MPa}$. This work focuses on modelling an industrial and commercial protein concentrate suitable for the both food and pharmaceutical industries, beginning from the algae cultivation to the protein extraction stage, and finally perform economic analysis.

Table 1.General Composition of Different Algae (\% of dry matter)

\begin{tabular}{llll}
\hline Algae & Protein & Carbohydrate & Lipids \\
\hline Anabaena cylindrical & $43-56$ & $25-30$ & $4-7$ \\
Aphanizomenon flos-aquae & 62 & 23 & 3 \\
Chlamydomonas rheinhardi & 48 & 17 & 21 \\
Chlorella pyrenoidosa & 57 & 26 & 2 \\
Chlorella vulgaris & $51-58$ & $12-17$ & $14-22$ \\
Dunaliella salina & 57 & 32 & 6 \\
Euglena gracilis & $39-61$ & $14-18$ & $14-20$ \\
Porphyridium cruentum & $28-39$ & $40-57$ & $9-14$ \\
Scenedesmus obliquus & $50-56$ & $10-17$ & $12-14$ \\
Spirogyra sp. & $6-20$ & $33-64$ & $11-21$ \\
Arthrospira maxima & $60-71$ & $13-16$ & $6-7$ \\
Spirulina platensis & $46-63$ & $8-14$ & $4-9$ \\
Synechococcus sp. & 63 & 15 & 11 \\
\hline
\end{tabular}

Source: Becker, 2007

Table 1.1 General Productivity of different Microalgae

\begin{tabular}{lll}
\hline Algal species & $\begin{array}{l}\text { Raceway pond depth } \\
(\mathrm{m})\end{array}$ & $\begin{array}{l}\text { Biomass Productivity } \\
\left(\mathrm{g} / \mathrm{m}^{2} / \text { day }\right)\end{array}$ \\
\hline Scenedemus $s p$. & 0.2 & 17 \\
Tetraselmis MUR 233 & 0.2 & $29.6(\max .-37.5$ \\
Spirulina Platensis & 0.3 & $8.2(\max -13.95)$ \\
Nannochloropsis sp & $0.15-0.2$ & 14.1 \\
Dictyosphaerium $s p$. & 0.3 & 5.8 \\
\hline
\end{tabular}




\subsection{Research Aims and Objectives}

The following are the research aims and objectives:

- To study the simulation of production of concentrated protein from microalgae through flash hydrolysis.

- To conduct techno-economic analysis of production of concentrated protein from microalgae at industrial/commercial scale.

- To discuss the inherent bottlenecks that hinder the feasibility of this novel process.

\subsection{Limitations}

The research does not incorporate the packaging, distribution, and transportation cost of the final product, the protein concentrate. Hence the prices employed in this work are not a true reflection of the protein concentrates on the market. Two kinds of power sources are suggested in this work: on-site power production and outside power. The cost of infrastructure for natural gas transportation and electricity transmission to the plant site was not included. 


\section{CHAPTER 2}

\section{OVERVIEW OF MICROALGAE}

\subsection{Algae Cultivation}

Algae are considered as potential feedstock candidates with higher productivity per unit land area as compared to traditional lignocellulosic biomass [Griffiths and Harrison, 2009]. They possess greater control of nutrient use, ability to receive and metabolize concentrated carbon dioxide from industrial sources, and consequently avoid competition with arable crops [Lardon et al., 2009]. There are many types of algal culture systems that have been built or proposed. Table 2 delineates different algal cultivation methods. Besides, the table shows the respective yields and cost of production quoted from literature.

Table 2 Algal culture systems, types, yields, and cost of production estimates.

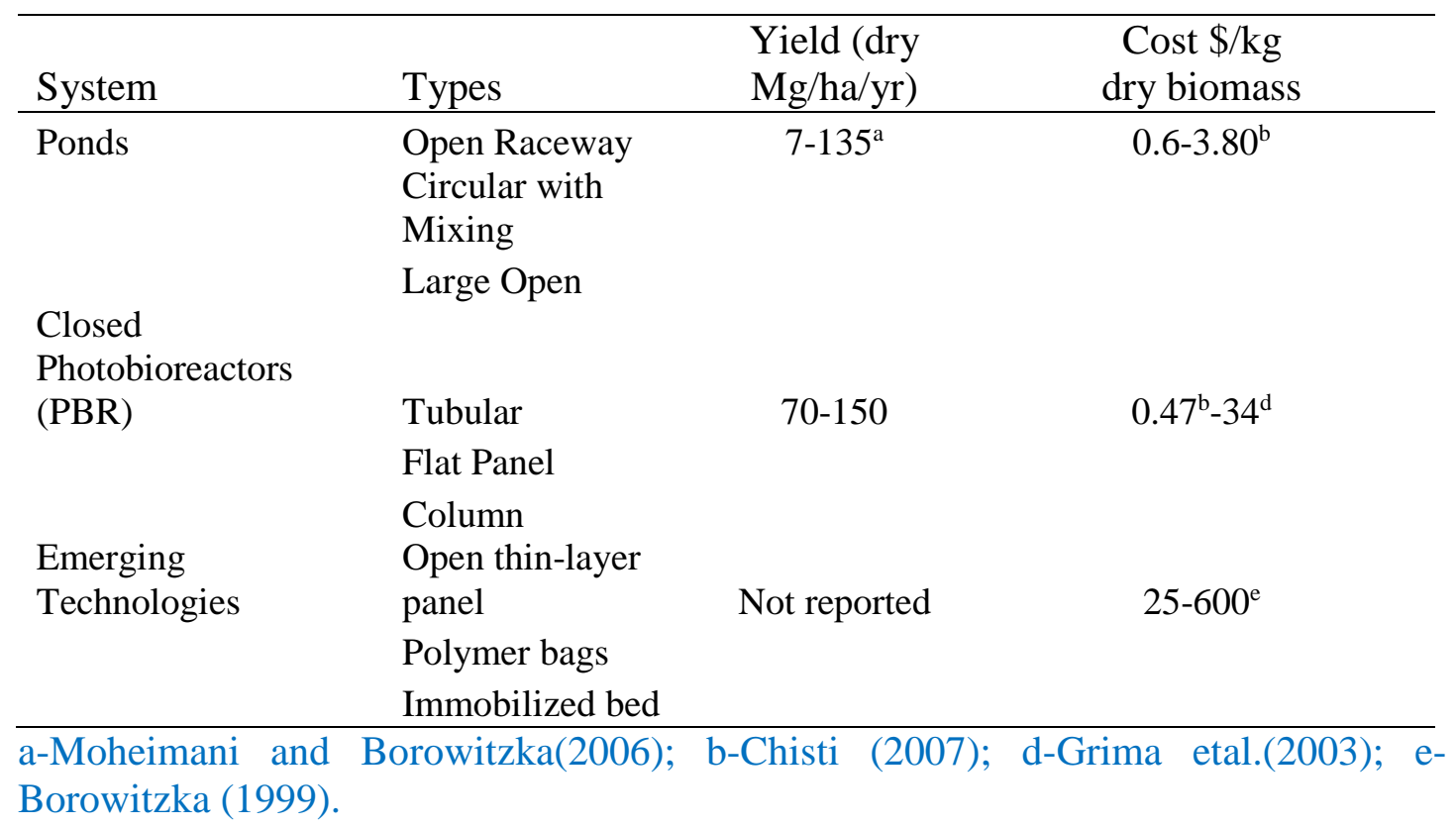


Though open pond systems require large acres of land and water to thrive, it is the least capital intensive. Conversely, closed system (PBR) lend itself to greater process control, but possesses higher capital cost. Emerging technologies on the other hand might offer better options to ponds and PBR, maybe yielding lower capital cost and higher cellular densities, giving total lower production cost. However, components such as polymer bags and immobilized bed are difficult to estimate. Besides, algae productivity and harvesting could be higher, but inherent hurdles such as high material cost, difficult scale-up, and proper strain identification for immobilized growth restrict the implementation and progress of emerging technologies [Katrina et al., 2012]. Due to the high capital demand open raceway pond are employed in this study.

\subsection{Water Resources}

The success of microalgae cultivation is contingent partly on reliable water supply. Due to the continuous evaporation of water from the open pond, make-up water needs to be supplied. PBR also require water for cooling purposes. There have been propositions that low competitive water, such as seawater and brackish water, could be used for algae cultivation. However, these sources require pre-treatments which results in high energy demand for the whole process. Moreover, water recycling has the potential of reducing consumption and nutrient loss, but it comes with greater risk of bacteria-fungi-virus infection and inhibition. Additionally, non-inhibitors such as organic and inorganic chemicals and remaining metabolites from destroyed algae cells are found in the recycled water [Slade et al., 2013]. In this work, it is assumed that $98 \%$ of the water for algae cultivation is recycled. 


\subsection{Land Use and Location}

Marginal land use has been suggested to be one of the advantages of algae cultivation since this limits its competition for food production. However, topographic and soil constraints limit the construction of raceway pond systems since they require flat terrain. Moreover, soil porosity calls for the need to line these ponds with polymeric and sealing materials thereby increasing cost of construction. Apart from land use, solar radiation required for algae cultivation is determined by the location of the pond. For practical purposes, suitable pond locations are warm countries near the equator (see Table 3) where insolation is not less than $3000 \mathrm{~h} / \mathrm{yr}$ [Slade et al., 2013].The average amount of solar radiation that reaches our planet every second, $E_{\text {solar, }}$ is about 1367 $\mathrm{W} / \mathrm{m}^{2}$, defined as the solar constant [Holtermann et al., 2011]. From Table 3, $q_{\text {solar,max }}^{n}$ is maximum irradiation intensity; $q_{\text {solar }}^{n}$ is the annual amount of irradiation; $\mathrm{v}$ is intensity of irradiations which describes the regularity of solar irradiation.

Table 3 Solar irradiation data for different locations

\begin{tabular}{lccc}
\hline Location & $\boldsymbol{q}_{\text {solar, } \boldsymbol{\text { max }}}^{\boldsymbol{n}}\left(\mathbf{W} / \mathbf{m}^{\mathbf{2}}\right)$ & $\boldsymbol{q}_{\text {solar }}^{\boldsymbol{n}}\left(\mathbf{k W h} / \mathbf{m}^{\mathbf{2}}\right)$ & $\mathbf{v}$ \\
\hline Bergen(Norway) & 828 & 785 & - \\
Helsinki(Finland) & 906 & 970 & 0.1338 \\
Stuttgart(Germany) & 974 & 1126 & 0.1419 \\
Madrid(Spain) & - & 1657 & 0.1943 \\
Lisbon(Portugal) & 1010 & 1726 & - \\
Rabat (Morocco) & - & 1837 & 0.2076 \\
Sahara Desert & - & 2350 & - \\
\hline
\end{tabular}

Source: Holtermann et al., 2011

Weyer et al reported that photosynthetic productivity is contingent on the intensity of the solar irradiation. Only the light within the wavelength range of 400 to $700 \mathrm{~nm}$, known as photosynthetically active radiation (PAR), can be used by plants and algae, which practically means that only 40 to $45 \%$ of total solar energy can be utilized for photosynthesis. Another group reported that the theoretical maximum for 
photosynthetic efficiency (PE) is between 8 and 11\% of the total solar energy [Brennan and Owende, 2010; Hindersin et al., 2013].

However, typical PE values of cultivated microalgae is reported to be in the range of 4 to 7\% under optimized condition [Doucha and Livansky, 2006, 2009; Hase et al., 2000; Morita et al., 2002].

\subsection{Nutrients}

The necessary nutrients for algae growth are primarily nitrogen, phosphorus, and potassium [Slade et al., 2013]. Others are calcium, magnesium and sulfur, which are necessary because biological molecules do not consist of carbon and water only. By assimilation, inorganic nutrients are converted into organic compounds to form part of the organisms’ biomass [Holtermann et al., 2011]. Moreover, since dry algal biomass consist of 7 wt\% nitrogen and 1 wt\% phosphorus, fertilization has become highly indispensable [Wijffels et al., 2010]. Ammonium nitrate and phosphate is used in this work as it contains nitrogen and phosphorus that essential nutrients for plants.

\subsection{Algae Bloom}

Excess nutrients input can lead to excessive algae growth. This will lead to deficiency of oxygen leading algae decomposition and eutrophication. Dead algae eventually precipitate and finally settle at the bottom of the water or any natural water or lake forming colloidal nutrient [Chipman et al., 2010, Sun et al., 2014]. Gao et al. and Zhu et al. reported that algae bloom causes a higher availability of P, Fe, and S. Sharp et al. and Shen et al. reported that algae bloom changes the physical and 
biological outlook of the benthic environment such as $\mathrm{DO}, \mathrm{pH}$, and Eh, particulate matter, which eventually affect the nutrient cycling.

\subsection{Carbon Dioxide}

Carbon content in microalgae emanates from atmospheric carbon dioxide. Moreover, there is a direct relationship between biomass output and $\mathrm{CO}_{2}$ consumption [Holtermann et al., 2011]. For example, 1 ton dry algae containing 50\% carbon by mass consumed 1.83 ton $\mathrm{CO}_{2}$. However, in reality, $\mathrm{CO}_{2}$ supply will be several factor of 1 tonne. For raceway pond, the outgassing is a function of the depth, friction coefficient of the lining, mixing velocity, $\mathrm{pH}$ and alkalinity. Depending on the operating conditions, the theoretical efficiency can range from 20\% to 90\% [Weissman et al., 1998]. Practically, the efficiency of $\mathrm{CO}_{2}$ fixation in open raceways may be less than $10 \%$; roughly $35 \%$ for thin layer cultivation the efficiency of $\mathrm{CO}_{2}$ [Slade et al., 2013]; approximately 75\% in closed tubular PBRs [Acién et al., 2012].

The source of $\mathrm{CO}_{2}$ can adversely affect the overall production cost of the process. It can also affect the choice of location of plant. $\mathrm{CO}_{2}$ supply from flue gas has been reported to cheaper than using raw $\mathrm{CO}_{2}$. It takes 3.7GJ of energy to absorb 1 tonne of $\mathrm{CO}_{2}$ from flue gas using monoethanolamine (MEA). About $370 \mathrm{~kg}$ of $\mathrm{CO}_{2}$ is released during $\mathrm{CO}_{2}$ absorption and regeneration of the MEA solution [Lam et al., 2012]

It is also advisable to site the flue gas source close to the algae production site. Since the cost of separating the $\mathrm{CO}_{2}$ from the flue gas is costly, the flue gas is directly fed to the algae pond. This injection does not affect the algae growth because the algae can tolerate the contaminants in the flue gas [Slade et al., 2013]. In this work $\mathrm{CO}_{2}$ is supplied by flue gas from an in situ power production that is powered by natural gas. Natural gas has been chosen because its flue gas is cleaner than that of coal that contains 
a lot of heavy metals (e.g. mercury), which can eventually contaminate the protein concentrate.

\subsection{Microalgae Harvesting}

Being one the technological steps in microalgae recovery from dilute algae culture, microalgae harvesting has been reported to have tasked the financial aspect in the bioenergy domain. Harvesting step contributes to $20-30 \%$ of the cost of microalgae production [Rawat et al., 2011]. The micro size of the algae grown in a very dilute culture (concentration less than $1 \mathrm{~g} / \mathrm{L}$ ) is the reason behind the high cost of harvesting [Danquah et al., 2009; Molina et al., 2003]. Moreover, microalgae possess a negative surface charge and their cells have algogenic organic matter that render them stable in a dispersed condition [Danquah et al., 2009]. Presently, there is no single economically viable and efficient microalgae harvesting method in the algae industry [Christenson et al., 2011]. However, combination of two or more harvesting methods can reduce cost of production [Schlesinger et al., 2012]. Table 4 highlights different methods, advantages and disadvantages of algae harvesting.

\subsection{Microalgae Conversion}

Microalgae is presently basically a source for biofuels, but to a lesser extent for bioactive components, such as protein. There are two general techniques for microalgae conversion: thermochemical and biochemical [Tsukahara and Sawayama, 2005]. While thermochemical conversion utilizes heat to decompose organic compounds in the algae, biochemical conversion employs microorganisms to produce biofuel. Thermochemical conversion can be subdivided into gasification, liquefaction, pyrolysis, and direct 
combustion. Biochemical on the other hand can be subdivided to into anaerobic digestion, alcoholic fermentation and photobiological hydrogen production. Other emerging conversion technologies are transesterification (acid/base) catalysis and photosynthetic microbial fuel cell are under research [Tan et al., 2015].

Table 4 Microalgae harvesting methods

\begin{tabular}{|c|c|c|}
\hline Harvesting method & Advantages & Disadvantages \\
\hline $\begin{array}{l}\text { Chemical Coagulation/ } \\
\text { flocculation }\end{array}$ & $\begin{array}{l}\text { - } \quad \text { Simple and fast method. } \\
\text { - } \quad \text { No energy requirement. }\end{array}$ & $\begin{array}{l}\text { - May be expensive and toxic to } \\
\text { algae. } \\
\text { - Culture medium recycle is } \\
\text { limited. }\end{array}$ \\
\hline Auto and bioflocculation & $\begin{array}{ll}\text { - } & \text { Inexpensive } \\
\text { - } & \text { Culture medium recycle } \\
\text { is permitted. } \\
\text { - Non-toxic to microalgae } \\
\text { biomass. }\end{array}$ & $\begin{array}{l}\text { - Cellular composition is } \\
\text { affected. } \\
\text { - Possibility of microbiological } \\
\text { contamination. }\end{array}$ \\
\hline Gravity Sedimentation & - $\quad$ Simple and inexpensive. & $\begin{array}{l}\text { - } \quad \text { Time-consuming. } \\
\text { - Possibility of biomass } \\
\text { deterioration. } \\
\text { - } \quad \text { Low concentration of algal } \\
\text { cake. }\end{array}$ \\
\hline Flotation & 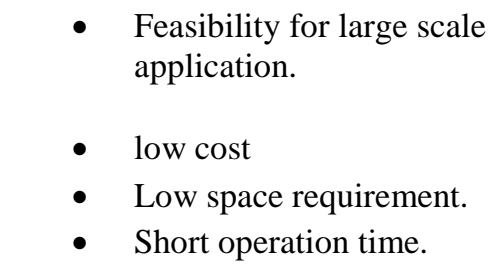 & $\begin{array}{l}\text { - } \quad \text { Requires the use of flocculants. } \\
\text { - Not applicable to marine algae } \\
\text { harvesting. }\end{array}$ \\
\hline $\begin{array}{l}\text { Electrical based } \\
\text { processes }\end{array}$ & $\begin{array}{l}\text { - Applicable to wide } \\
\text { variety of algae sp. } \\
\text { Do not require the use of } \\
\text { flocculants. }\end{array}$ & $\begin{array}{l}\text { - } \quad \text { Poorly disseminated. } \\
\text { - High energy and equipment } \\
\text { cost. }\end{array}$ \\
\hline Filtration & $\begin{array}{l}\text { - High recovery } \\
\text { efficiency. } \\
\text { - } \quad \text { Allow separation of } \\
\text { shear sensitive sp. }\end{array}$ & $\begin{array}{l}\text { - } \quad \text { Possibility of fouling/clogging. } \\
\text { chequire regular membrane } \\
\text { change. } \\
\text { High cost of pumping and } \\
\text { membrane. }\end{array}$ \\
\hline Centrifugation & $\begin{array}{ll}\text { - } & \text { Fast method. } \\
\text { - } & \text { High recovery efficiency } \\
\text { - } & \text { Suitable for almost all } \\
\text { microalgae sp. }\end{array}$ & $\begin{array}{ll}\text { - } & \text { Expensive. } \\
\text { - } & \text { High energy requirement. } \\
\text { Possibility of cell damage to } \\
\text { high shear forces. } \\
\text { - } \\
\quad \text { Suitable for high-valued } \\
\text { product recovery. }\end{array}$ \\
\hline
\end{tabular}

Source: Ana et al., 2015 


\subsection{Liquefaction}

This reaction converts wet algae biomass to bio-oil at low temperature and high pressure by either employing a catalyst or not. In this case energy intensive drying process is unnecessary. This process does not only convert lipids but also carbohydrates and protein in the algae into biocrude oil [Biller and Ross, 2011]. The efficiency of thermochemical liquefaction is contingent on reaction temperature, retention time, catalyst, and composition of biomass (liquid, carbohydrate, and protein) [Yang et al., 2004].

Hydrothermal liquefaction is a type of liquefaction process that employs subcritical water at medium temperature of $280-370^{\circ} \mathrm{C}$ and pressure range of $10-25$ MPa. This also converts wet biomass into liquid biocrude as the main product. (Patil et al., 2008).

\subsection{Anaerobic Digestion}

Anaerobic digestion is one of the biochemical conversion methods that utilize microorganisms to convert algae biomass into biogas comprising $\mathrm{CH}_{4}$ and $\mathrm{CO}_{2}$ with small amount of $\mathrm{H}_{2} \mathrm{~S}$. Biogas has energy content of $20-40 \%$ of the original lower heating value of the biomass. The optimum moisture content of biomass that is suitable for anaerobic digestion is in the range of $80-90 \%$ dry weight [Brennan and Owende, 2010].The three anaerobic stages are: hydrolysis of polysaccharides; fermentation (sugar to alcohol acetic acid, volatile fatty acid and mixture of $\mathrm{H}_{2}$ and $\mathrm{CO}_{2}$ ); methanogenesis (conversion of gas mixture into $\mathrm{CH}_{4}(60-70 \%)$ and $\mathrm{CO}_{2}(30-40 \%)$ ) [Cantrell et al., 2008)]. Knowing the carbon, hydrogen, oxygen and nitrogen content of the biomass, the theoretical production of methane can be illustrated by the following stoichiometric equation [Ward et al. 2014]: 
$\left(C_{a} H_{b} O_{c} N_{d}\right)+\left(\frac{4 a-b-2 c+3 d}{4}\right) H_{2} \rightarrow\left(\frac{4 a+b-2 c-3 d}{8}\right) C H_{4}+\left(\frac{4 a-b+2 c+3 d}{8}\right) \mathrm{CO}_{2}+d N H_{3}$ where a, b, c, and d equal the carbon, hydrogen, oxygen, and nitrogen contents on molar basis respectively. Methane yield (litres/g (VS) destroyed) is found as follows:

$$
\left(\frac{4 a+b-2 c-3 d}{12 a+b+16 c+14 d}\right) * V_{m}
$$

Where $\mathrm{V}_{\mathrm{m}}$ is the molar volume $(22.14 \mathrm{~L} / \mathrm{mol})$ at $0^{\circ} \mathrm{C}$ and $1 \mathrm{~atm}$.

\subsection{Flash Hydrolysis}

From the preceding discussion on the different kinds of reactions, the end products are biofuels (diesel, methane, hydrogen, ethanol, etc.).

Flash Hydrolysis is a reaction between subcritical water (temperature less than $374^{\circ} \mathrm{C}$ and pressure less than $20 \mathrm{MPa}$ ) and algae in a continuous plug-flow reactor with residence time of few seconds. This reaction does not produce biocrude oil; it does produce protein-laden aqueous phase and solid phase (containing biofuel intermediate). The short time does not allow the conversion of protein and carbohydrate to convert to biocrude oil as reported by Valdez and Savage, 2013 and Valdez et al., 2014. Subjecting the microalgae biomass to liquefaction condition for a long time eventually convert most of protein, carbohydrate, and lipid into biocrude oil as shown in Figure 1. This means that to produce more protein in the aqueous phase, the reaction time should be in seconds as reported by Garcia-Moscoso et al. 


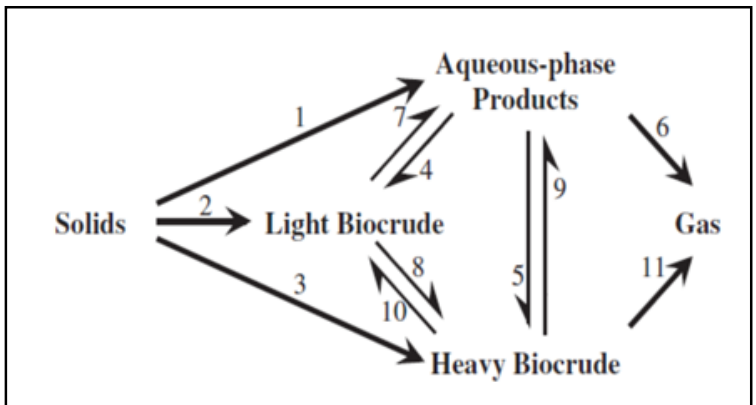

(a)

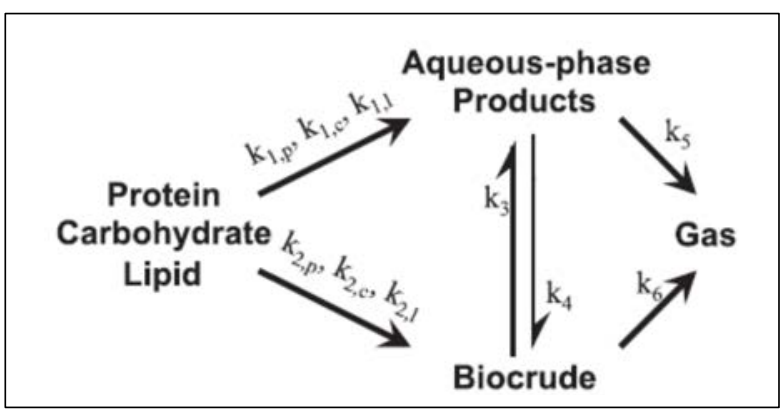

(b)

Figure1.Reaction network for the hydrothermal liquefaction of Nannochloropsis sp.

Garcia-Moscoso et al. reported a flash hydrolysis in a continuous-flow reactor whereby the protein from microalgae (Scenedesmus sp.) biomass was hydrolyzed in a very short residence time (few seconds). In their work, flash hydrolysis was conducted at different temperatures $\left(240,280\right.$, and $\left.320^{\circ} \mathrm{C}\right)$ and in three different residence times (6, 9 and 12 sec.). They concluded that the maximum yield of protein in the aqueous phase was approximately $82 \%$ at $320^{\circ} \mathrm{C}$ in 6 seconds. Based on this work, it has been proposed that extraction and concentrating protein from microalgae is feasible and environmentally friendly on commercial scale as compared to solvent extraction methods. 


\section{CHAPTER 3}

\section{COST OVERVIEW}

\subsection{Overview of Process Economics}

Process economics is an indispensable component of every new product or process design. In designing a new process or product, many of the technical and environmental decisions are strongly influenced by economic factors. It is therefore necessary to discuss the economic aspect of this simulation. The knowledge of economics will assist in evaluating the feasibility of the process, making improvements, comparing alternatives, making design and operating decisions, etc. These decisions can be made based on (1) cost and estimate of operation; (2) depreciation; (3) breakeven analysis (i.e. total production cost equals process revenue); (4) time value of money; (5) profitability analysis [El-Halwagi and Mahmoud, 2012 ].

\subsection{Cost Types and Estimation}

There are two basic cost used to make decisions in process economics: capital investment and operating cost. The total capital investment (TCI) or capital cost is the money required to purchase and install the plant and its accessories and to provide the requisite expenses needed to start the process operations. With the plant in operation, the money required to continue or run the operation is known as the operating cost. The basis for estimating these two costs are (i) capital (fixed, working, and total), (ii) equipment, (iii) operating, and (iv) production (total annualized cost). The fixed capital investment/cost is the money required to pay for the processing equipment and the auxiliary units, acquiring and preparing land, civil structures, facilities, and control systems. On the other hand, the working capital is the money needed to pay for the 
operating expenses until the product is sold. It also includes the money needed to stockpile raw materials. The following outlines the estimation of fixed capital cost. The fixed capital (FC) is estimated based on total equipment purchase cost (PC).

$\mathrm{FC}=$ Direct Cost (DC) + Indirect Cost (IC) + Other Cost (OC). The rest of the cost analysis can be found in the appendix.

The word estimate implies, there is a level of uncertainty in most cost estimates. These uncertainties emanate from the method or source of cost acquisition. The most commonly used methods are (i) manufacture’s quotation, (ii) computer-aided tools, (iii) capacity ratio with exponent, (iv) updates using cost indices, (v) factor based on equipment cost, (vi) empirical correlations, and (vii) turnover ratio [El-Halwagi and Mahmoud, 2012 ].

Capacity ratio with exponent can be evaluated from the following equation.

$$
F C I_{B}=F C I_{A}\left(\frac{\text { Capacity }_{B}}{\text { Capacity }_{B}}\right)^{x}
$$

where $\mathrm{FCI}_{\mathrm{B}}$ and $\mathrm{FCI}_{\mathrm{A}}$ are the fixed capital investments of plant $\mathrm{B}$ and A respectively, and Сарасityв and Сарасity are the capacities (for example, flow rate of main product) of plants B and A respectively, the exponent $x$ is usually less than 1 (taken to be 0.60.7). This relation can also be applied to equipment estimation if the sizes of the equipment are known and the cost of one them is known.

Cost estimates are made and reported for a given time. With inflation and price fluctuation, it is necessary to account for fixed capital cost as a function of time. Cost indices are very useful in adjusted cost estimates based on time. Updates using cost indices can be applied using the following equation.

$$
F C I_{t 2}=F C I_{t 1}\left(\frac{\text { Cost index at time } t 2}{\text { Cost index at time } t 1}\right)
$$

Where $\mathrm{FCI}_{\mathrm{t} 1}$ and $\mathrm{FCI}_{\mathrm{t} 2}$ are the cost of plant/equipment at times $\mathrm{t} 1$ and $\mathrm{t} 2$ respectively. 
Methods used to estimate the capital cost in the present study are the capacity/size ratio and updates using cost indices. These are imbedded in the SuperPro Designer software.

\subsection{Depreciation}

Depreciation is the annual income tax deduction that is intended to allow a company to recover the cost of property (for example, ultrafiltration unit) over a certain recovery period [El-Halwagi and Mahmoud, 2012]. This is normally taken from the revenue before tax so that the cost of equipment can be recovered and to perpetuate the use of the property or asset. Land and working capital investment cannot be depreciated because they are recoverable in principle. There are several method to calculate depreciation: (i) linear (straight-line) method; (ii) declining-balance method; (iii) modified accelerated cost recovery system ;( iv) sum-of-years' digit method; (v) sinking fund method. The detail explanation of each is not explained in this work. However, the simplest and most commonly used is the method of the straight-line. In this work, the straight-line method was used in the SuperPro Designer.

\subsection{Profitability Analysis}

This can be done with or without time-value of money. Profitability criteria without time-value money are (i) return on investment (ROI) and (ii) payback period (PB). Whereas profitability criteria with time-value of money are (i) net present value (NPV); (ii) discounted cash flow return on investment (DCF ROI); (iii) discounted cash flow payback period. Another way of assessing profitability is by comparison of alternatives through (i) NPV; (ii) annual cost/revenue; (iii) total annualized cost; (iv) incremental return on investment. 
$\mathrm{ROI}=\frac{\text { Annual Profit }}{\text { Total Capital investment }} \times 100 \%$

NPV is the cumulative value (revenues-expenses) adjusted to a reference time. It is found as NPV $=\sum_{N=0}^{N} A C F_{N}(1+i)^{-N}$, where $\mathrm{ACF}_{\mathrm{N}}$ is annual cash flow for year $\mathrm{N}$, $\mathrm{i}$ is the discount rate. NPV $>0$ means investment is financially attractive; NPV $=0$ means the investment is neutral; NPV $<0$ means the investment is not financially attractive.

The DCF ROI also known as internal rate of return (IRR) is the value of discount rate that renders the NPV to be zero. The higher IRR value the more attractive the project [Edgar and Himmelblau, 2001]. The total annualized cost (TAC) is equal to the sum of annualized fixed cost (AFC) and the annual operating cost (AOC). This is calculated as TAC $=\mathrm{FCI}^{*} \frac{i(1+i)^{N}}{(1+i)^{N}-1}+A O C$. Thus the AFC is multiplied by the capital recovery factor and the result is added to the annual operating cost. This gives the annual cost needed to perpetuate the project by taking care of operating cost and capital investment. 


\section{CHAPTER 4}

\section{SIMULATIONS}

\subsection{Process Modelling}

Scenedesmus obliquus algae was selected for this work since it is the kind grown at Old Dominion Algae Laboratory. Elemental analysis of this algae is as follows: $\mathrm{C}=50 \%, \mathrm{H}=6.2 \%, \mathrm{~N}=9.65 \%, \mathrm{P}=1 \%$, and $\mathrm{O}=32 \%$. This gives the empirical formula for the algae as $\mathrm{C}_{133} \mathrm{H}_{192} \mathrm{O}_{32} \mathrm{~N}_{22} \mathrm{P}$. This formula was used to calculate for the nutrient requirements. Rogers et al. reported similar empirical formula as $\mathrm{C}_{106} \mathrm{H}_{181} \mathrm{O}_{45} \mathrm{~N}_{16} \mathrm{P}$. The following were the principal assumptions made.

\subsection{Essential Assumptions}

- Algae strain: Scenedesmus obliquus

- Elemental composition of algae biomass: $\mathrm{C}_{133} \mathrm{H}_{192} \mathrm{O}_{32} \mathrm{~N}_{22} \mathrm{P}$

- Average annual areal productivity: $15 \mathrm{~g} \mathrm{~m}^{-2} \mathrm{~d}^{-1}$

- Biomass Protein Content: 54 wt.\%

- Daily peptide production: $160 \mathrm{MT} / \mathrm{day}$

- Protein Extraction efficiency: 85\%

- Harvested algae slurry: 20 wt. \%

- Dimensions of a pond: $120 \mathrm{~m}$ x $10 \mathrm{~m}$ x $0.3 \mathrm{~m}$

- Maximum culture density: $0.8 \mathrm{~g} \mathrm{~L}^{-1}$

- Water recycle rate: $98 \%$ 


\subsection{Process Description}

A simplified process flowsheet for $95 \mathrm{wt} . \%$ protein concentrate is as shown in Fig.2.

The process was modelled with SuperPro ${ }^{\circledR}$ Designer V. 9.0. Fig. A1 highlights the modelling of the algae cultivation, harvesting and protein extraction. The algae is grown in a raceway pond $\mathrm{P}-2$ with ammonium phosphate and ammonium nitrate as the necessary nutrients. Carbon dioxide is supplied by the flue gas from an integrated cogeneration section. The growth maturity was assumed to 14 days at which the algae concentration will have reached $0.8 \mathrm{~g} / \mathrm{L}$. The culture is then pumped by pump P-6 to be filtered by the belt filter BF-101. The wash-out outlet is recycled back to the pond. The cake density is set to $20 \mathrm{wt}$. \% necessary for the flash hydrolysis. The slurry is stored in vessel V-101 awaiting flash hydrolysis. The algae slurry is then pumped by PM-102 through series of heat exchangers $\mathrm{HX}-102$ to be heated from $20^{\circ} \mathrm{C}$ to $280^{\circ} \mathrm{C}$. The slurry is then subjected to flash hydrolysis within 10 seconds in a plug flow reactor PFR-101. The products are cooled to $30^{\circ} \mathrm{C}$, and are then sent to belt filter $\mathrm{B}-102$ to remove the solid part of the algae (biofuel intermediate). The pregnant protein solution is then subjected series of ultrafiltration by UF-101 giving $40 \mathrm{wt}$.\% concentrated proteins. The protein concentrate is subjected to spray drying where it allowed to move countercurrent to a hot stream of air $\left(140^{\circ} \mathrm{C}\right)$ in the dryer (SDR-101). The dry protein is collected at the bottom of the dryer while the exhaust air $\left(70^{\circ} \mathrm{C}\right)$ is sent to the cyclone (CY-101) to recover protein fines.

The filtrates from both BF-102 and UF-101 are sent to anaerobic digester AD101 for methane production. Since the methane generated is not enough to produce power and carbon dioxide for the entire process, natural gas is employed to supplement the power production. Natural gas is combusted in a boiler SG-101 to produce steam at 
$6 \mathrm{MPa}$ and $300^{\circ} \mathrm{C}$. The steam is sent to a multi-staged power generator T-101 for power production. The flue gas from the boiler SG-10, which contains $18 \%$ carbon dioxide is cooled to $30^{\circ} \mathrm{C}$ through heat exchanger $\mathrm{HX}-103$ and sent to the algae pond. The steam generated from the power house is used to heat the algae slurry for the hydrolysis.

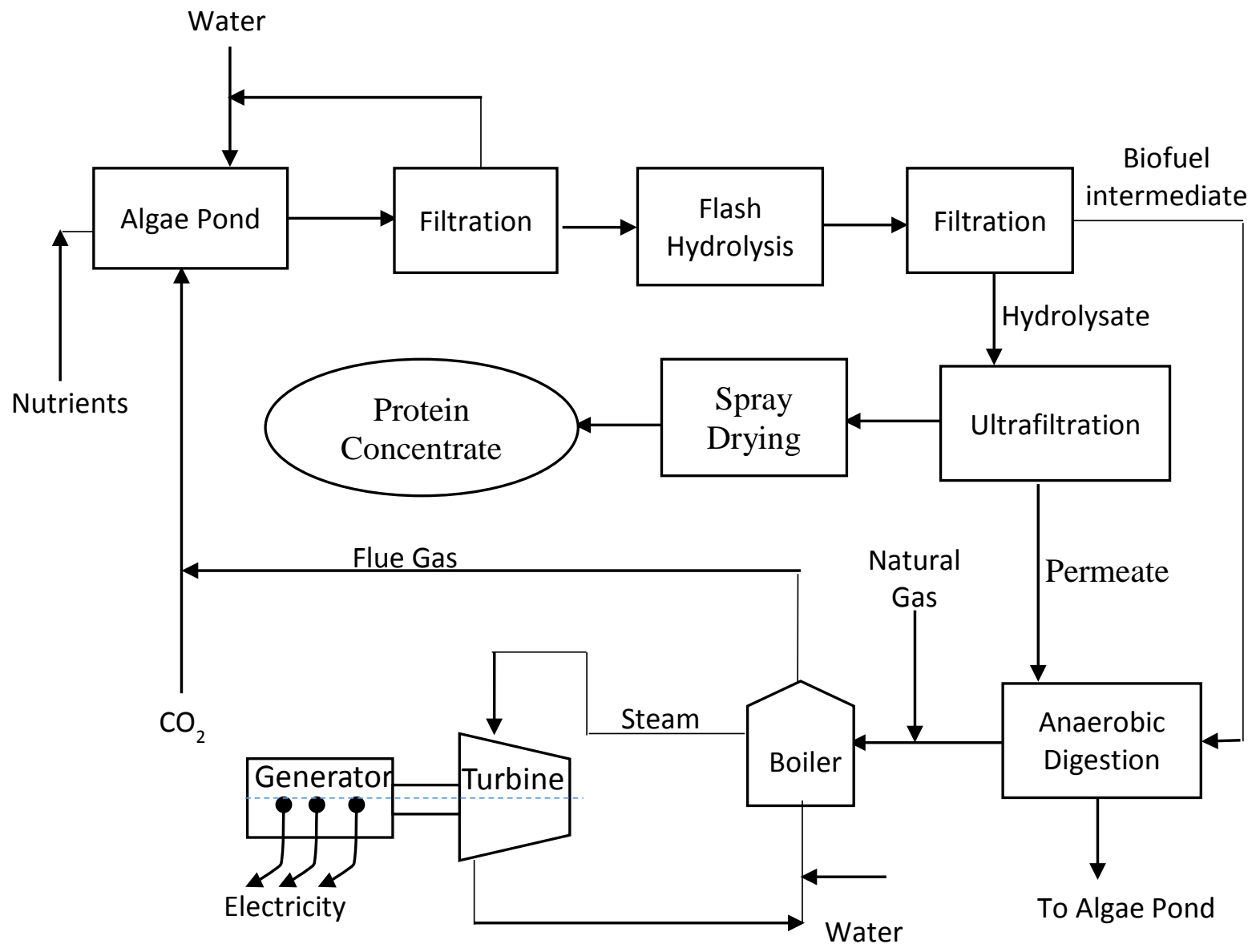

Figure 2. Simplified Process flowsheet for protein concentrate production. 


\subsection{Economic Analysis}

Numerous studies have evaluated the economics of microalgae production, but most of them concentrate on biofuel production (Amer et al., 2011; Benemann, 2013; Davis et al., 2011; Draaisma et al., 2013; Lam and Lee, 2012; Rios et al., 2013; Taylor et al., 2013). Richardson et al. reported Farm-level Algae Risk Model (FARM) and used it to simulate the economic feasibility and probabilistic cost of biomass and biocrude oil production for two projected algae farms. Rogers et al. also reported sustainability and economic requirements of a 160 MT/day algal biofuel facility based in New Mexico. Since the outcome their work cannot be substituted for the current work, it is necessary to assess the actual financial viability of protein concentrate as opposed to biofuel production.

In this work, it is assumed that the year of construction is 2015; construction period is three years; start-up period is one year; project life is 15 years; inflation (to update equipment cost) is $4 \%$; interest rate is $10 \%$. In financing the project, $30 \%$ of the fixed capital investment is provided in the first year, $40 \%$ in the second year, and $30 \%$ in the third year. Concerning depreciation, straight line method was employed with salvage value being $5 \%$ of the fixed capital. Moreover, the operation hours is assumed to be 7920 /year (330days/year). The cost of materials and equipment is obtained from the SuperPro Designer. Other assumed parameters include the following: Pond paddlewheel (\$5000/unit); energy requirement for a paddlewheel $\left(0.73 \mathrm{~W} / \mathrm{m}^{2}\right)$; pond liner $\left(\$ 0.77 / \mathrm{m}^{2}\right)$; Landscaping $\left(\$ 0.16 / \mathrm{m}^{2}\right)$, raceway covering $\left(\$ 0.98 / \mathrm{m}^{2}\right)$ [Rogers et al., 2014]. 
Table 5. Capital Cost estimation for 160 MT/day protein concentrate

\begin{tabular}{lrrr}
\hline & & & Total Cost \\
Name Description & Quantity & Unit Cost $(\$)$ & $(\$ \mathbf{M})$ \\
\hline MX-101 Mixer & 28 & 2000 & 0.15 \\
Algae Pond & 19138 & 8000 & 153.104 \\
PM-101 Centrifugal Pump & 3 & 206000 & 0.618 \\
PM-103 Centrifugal Pump & 1 & 55000 & 0.050 \\
V-101 Receiver Tank & 1 & 55000 & 0.055 \\
PM-102 Centrifugal Pump & 3 & 187000 & 0.561 \\
PM-104 Centrifugal Pump & 1 & 45000 & 0.045 \\
M-101 Centrifugal Fan & 1 & 16000 & 0.016 \\
PFR-101 Plug Flow Reactor & 1 & 75000 & 0.075 \\
HX-101 Heat Exchanger & 6 & 130000 & 0.780 \\
UF-101 Ultrafilter & 245 & 147000 & 36.015 \\
SG-101 Steam Generator & 2 & 975000 & 1.950 \\
T-101 Multi-Stage Steam & & & \\
Turbine & 1 & 4115000 & 4.115 \\
MX-102 Mixer & 28 & 2000 & 0.056 \\
MX-103 Mixer & 1 & 2000 & 0.002 \\
MX-106 Mixer & 1 & 2000 & 0.002 \\
HX-102 Heat Exchanger & 75 & 2000 & 0.15 \\
AD-101 Anaerobic Digester & 2 & 6136000 & 12.272 \\
MX-106 Mixer & 1 & 2000 & 0.002 \\
HX-102 Heat Exchanger & 8 & 126000 & 1.008 \\
HX-103 Heat Exchanger & 1 & 122000 & 0.610 \\
HX-104 Heat Exchanger & 5 & 54000 & 0.054 \\
BF-101 Belt Filter & & 280000 & 3.920 \\
BF-102 Belt Filter & & 303000 & 1.400 \\
SDR-101 Spray Dryer & & 3000 & 0.303 \\
CY-101 Cyclone & & 3000 & 0.006 \\
Land Acquisition (Acres) & & & 21.530 \\
Equipment installation & & & 27.834 \\
Startup Cost & & & 12.244 \\
Working Capital & 177.402 \\
Total & & &
\end{tabular}

*This is excluded from the fixed capital investment. 
Table 6 Annual Operating Cost for 160 MT/day Protein Concentrate

\begin{tabular}{|c|c|c|c|c|}
\hline $\begin{array}{l}\text { Bulk } \\
\text { Material }\end{array}$ & $\begin{array}{r}\text { Unit } \\
\text { Cost }(\$)\end{array}$ & $\begin{array}{r}\text { Annual Amount } \\
(\mathrm{MT})\end{array}$ & Units & $\begin{array}{r}\text { Annual Cost } \\
(\$ M)\end{array}$ \\
\hline Labor & 69.000 & 88829 & hrs & 6.129 \\
\hline Ammonium Nitrate ${ }^{*}$ & 0.150 & 46023 & MT & 6.903 \\
\hline Carbon dioxide* & 40.000 & 3523 & MT & 0.141 \\
\hline Diammonium Phosphate* & 0.500 & 4744 & MT & 2.372 \\
\hline Methane* & 0.136 & 76074 & MT & 10.346 \\
\hline Water ${ }^{*}$ & 0.013 & 5135536 & MT & 0.668 \\
\hline Dft Membrane & 400.000 & 27413 & $\mathrm{~m}^{2}$ & 10.965 \\
\hline Power (kWh) & 0.100 & 191883086 & kWh & 19.188 \\
\hline Steam (High P) & 20.000 & 979713 & $\mathrm{MT}$ & 19.594 \\
\hline Cooling Water & 0.050 & 107724417 & MT & 5.386 \\
\hline Facillity-dependent ${ }^{\mathrm{a}}$ & & & & 62.742 \\
\hline Laboratory/QC/QA ${ }^{\mathrm{b}}$ & & & & 0.919 \\
\hline Waste Treatment $^{\mathrm{C}}$ & & & & 1.099 \\
\hline Total & & & & 146.452 \\
\hline
\end{tabular}

a Estimate based on capital investment parameters (i.e., maintenance, depreciation and miscellaneous costs).

$\mathrm{b}$ This accounts for the cost of off-line analysis, quality control (QC) and quality assurance (QA).

c 1 barrel of peptide concentrate costs $\$ 3.33$ wastewater treatment.

*These are the main inputs to the SuperPro Designer. 


\section{CHAPTER 5}

\section{RESULTS AND DISCUSSIONS}

In this work, protein concentrate of $160 \mathrm{MT} /$ day commercial facility has been analyzed. This throughput requires 336 MT/day dry algae. The amount of carbon dioxide required to grow these microalgae is estimated to be $648 \mathrm{MT} / \mathrm{day}$, which is produced from an in situ 21-MW power plant run by approximately $12 \mathrm{MT} / \mathrm{h}$ natural gas (methane). This means the cost of supplying carbon dioxide to the pond is approximately $4 \%$ of the operating cost. Ketheesan et al. reported that the cost of supply and transfer of $\mathrm{CO}_{2}$ accounts for nearly one-third of the total algal cultivation cost. Li et al. also reported that the cost of the carbon source in the algal medium ranges from 8 to $27 \%$ of the daily production cost. The amount of water consumed in the entire process is estimated to be $15,576 \mathrm{MT} / \mathrm{day}$. With the area of 0.3 acre per pond, the total area require for the facility is approximately 7177 acres inclusive of area required for downstream process equipment.

The fixed capital investment (FCI) and the annual operating cost (AOC) for the production of $160 \mathrm{MT} /$ day of protein concentrate via flash hydrolysis are estimated to be 264 million and 145 million US Dollars respectively. It is worth noting that the value of FCI excludes the cost of land acquisition. Moreover, it is evident that the FCI is contingent on the algae cultivation stage, which is driven by the algae pond construction. The major drivers here are the pond liner, paddle wheel, and pond cover while landscaping plays the minor role (Fig 3 and 3.1). The other major FCI drivers are cost of equipment installation, ultrafiltration, filtration and anaerobic digestion. This result is in agreement with the work of Rogers et al.

Operating cost, on the other hand, is controlled by facility-dependent cost, which comes from maintenance, depreciation and other miscellaneous cost. Utilities 
cost is due to huge energy consumption by pumping, heating and cooling, and pond agitation (Table 6 and Fig.4). The total power consumption (19.5 MW) is dictated by energy-intensive equipment summarized in Table 7. Algae growth consumed approximately $94 \%$ of the total power used in this work.

Apart from the main product (protein concentrate), power generation contributes moderately (3\%) to the revenue of this project. Moreover, Low and high pressure steam, which is considered as additional credit contributes approximately $5 \%$ to the revenue. These percentages are based on the minimum product prices of $\$ 4.13$ (see Table 8). The minimum value of the protein concentrate is calculated using excel solver. This is illustrated in Table A1 in the appendix.

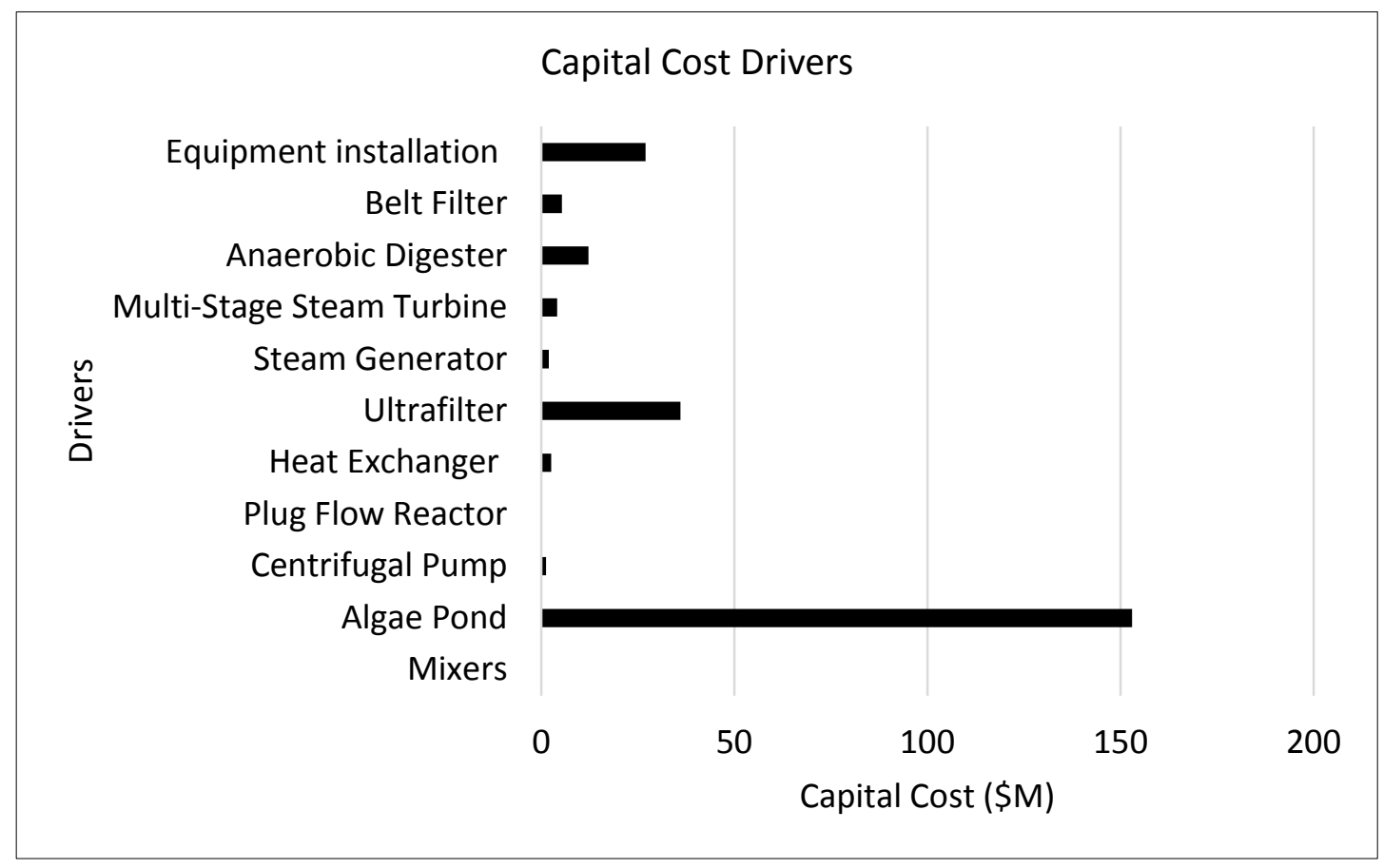

Figure 3 Capital Cost Drivers 


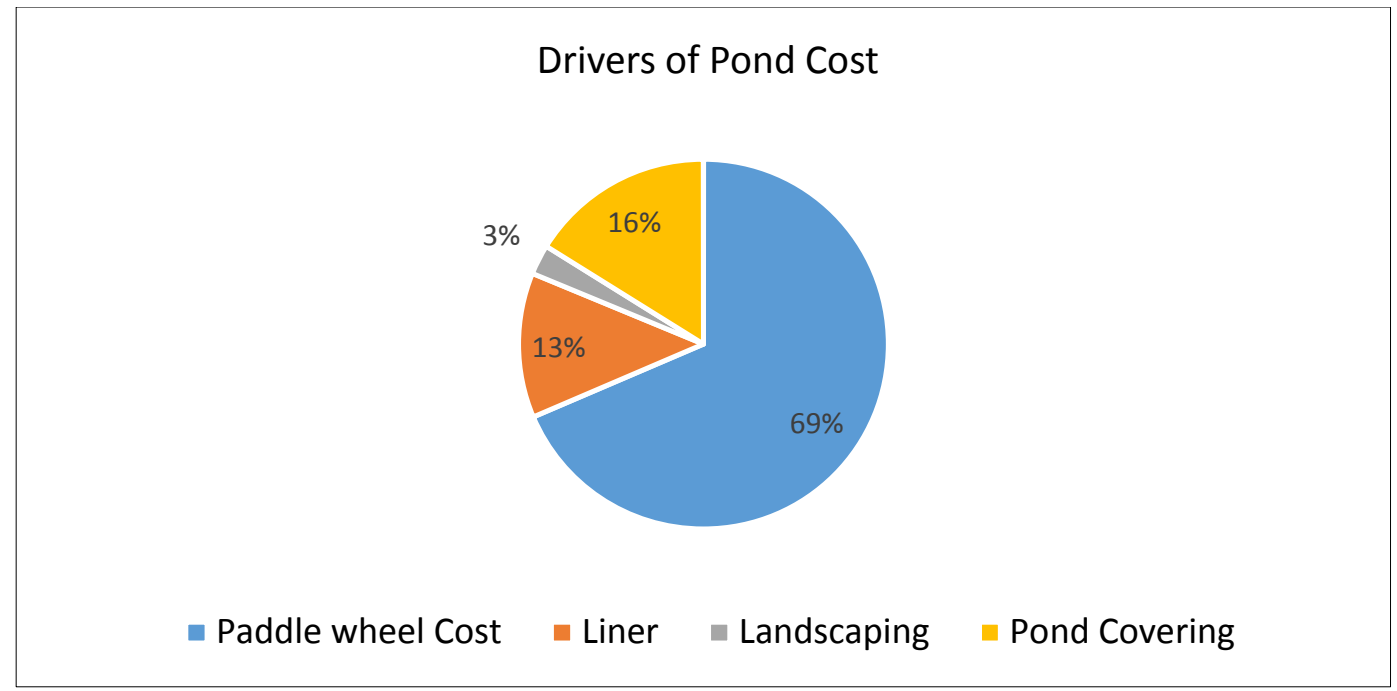

Figure 3.1 Drivers of Pond Cost

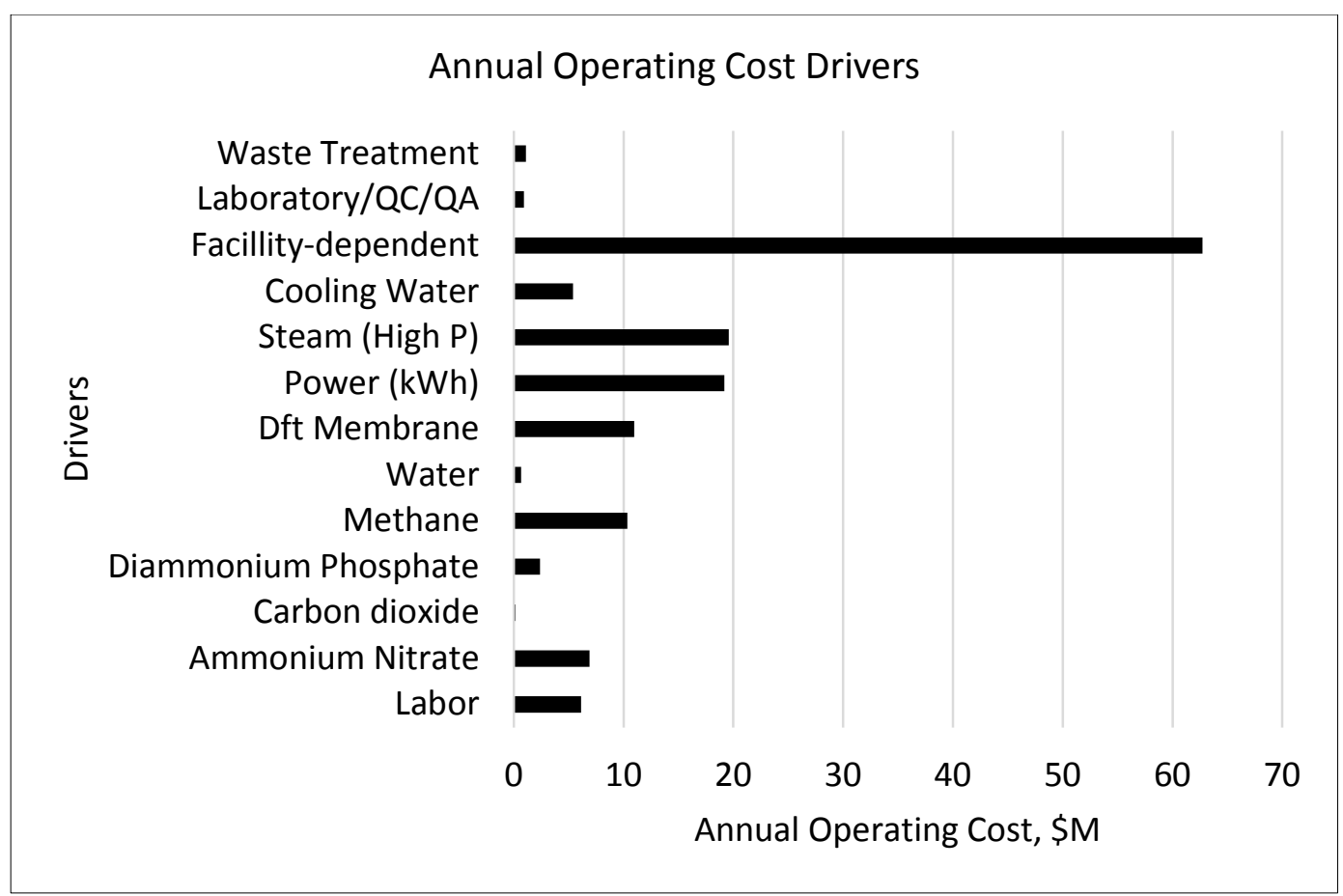

Figure 4 Annual Operating Cost Drivers 
Table 7 Energy consumption at the various sections

\begin{tabular}{lr}
\hline Section & Power $(\mathrm{kwh} / \mathrm{h})$ \\
\hline Algae Growth & 16765 \\
Biogas Production & 166 \\
Ultrafiltration & 652 \\
Pumping & 1441 \\
Drying & 359 \\
\hline
\end{tabular}

Table 8 Revenue/Credit Summary for 160 MT/day of Protein Concentrate

\begin{tabular}{lrrrrr}
\hline Description & Rate & Rate Unit & Price & Price Unit & Revenue $(\$ \mathrm{M})$ \\
\hline Power Generation & 168412221 & $\mathrm{kwh} / \mathrm{yr}$ & 0.08 & $\$ / \mathrm{kWh}$ & 13.472 \\
Protein Concentrate & 50688 & $\mathrm{MT} / \mathrm{yr}$ & 4.13 & $\$ / \mathrm{kg}$ & 209.341 \\
Total & & & & & $\mathbf{2 2 2 . 8 1 3}$ \\
\hline
\end{tabular}

\subsection{Sensitivity Analysis}

Results from this simulation gave the following baseline values: FCI of \$264 million, AOC of $\$ 145$ million, Annualized cost of $\$ 180$ million, unit cost of $\$ 2.86 / \mathrm{kg}$ protein, and a minimum product price of $\$ 4.13 / \mathrm{kg}$. These values can be compared to some of the protein prices on the market (Fig. A3). These values are controlled by the kind of microalgae employed, algae productivity, nature or kind of pond (depth, lined, open, mixing power, kind of nutrients etc.), algae slurry to the flash hydrolyzer, percent algae conversion in the hydrolysis, protein content in the algae, percent of total water recycle, project life, discount rate, tax rate, debt/equity ratio etc. This section is dedicated to analyzing how some of these factors affect the financial and technical aspect of this work. 


\subsection{Effect of Flash Hydrolysis Percent Conversion}

The percent conversion in the flash hydrolysis was pegged at $85 \%$, which affected the quantity of protein extracted. Changing the percent algae conversion from $85 \%$ to $95 \%$ produced a protein throughput from 6.4 to $7.1 \mathrm{MT} / \mathrm{h}$. While the concentrated protein price from $\$ 4.13 / \mathrm{kg}$ to $\$ 3.71 / \mathrm{kg}$, the unit cost of protein changed from $\$ 2.86 / \mathrm{kg}$ to $\$ 2.56 / \mathrm{kg}$ (see Figures 5.1). However, changing the percent conversion did not affect the AOC and the FCI since none of the factors that affect AOC and FCI was affected by the change in percent conversion.

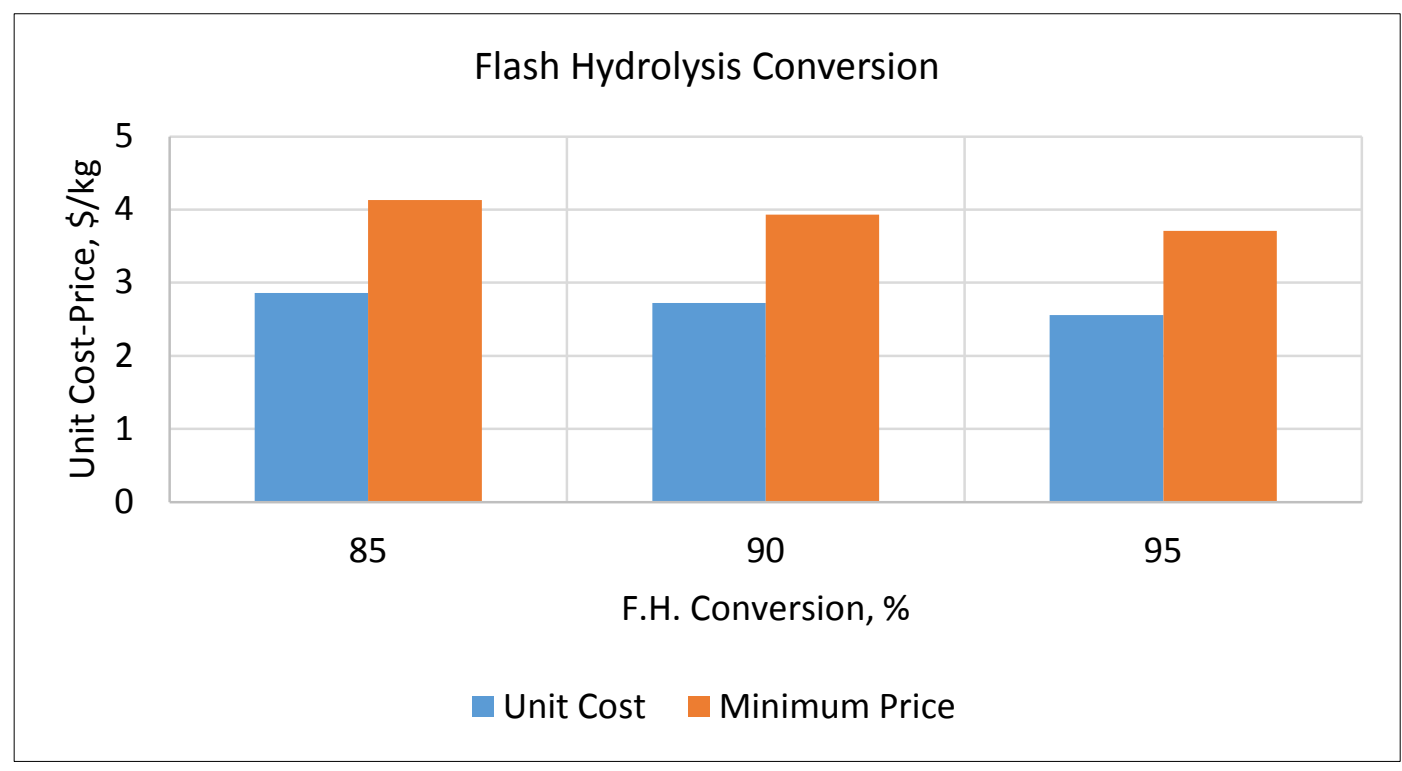

Figure.5.1 Flash Hydrolysis (F.H.) Conversion

\subsection{Effect of Pond Depth}

In this simulation, the baseline pond depth was is assumed to be 0.3 meters. This has tremendous effect on the amount of light used and consequent algal productivity. Changing the pond depth affected the FCI, AOC, acres of land use, protein price and unit cost. Changing the pond depth from 0.3 to 0.4 meters (Fig. 5.2) did prompt the FCI to dip greatly by $16 \%$ ( $\$ 264 \mathrm{M}$ to $\$ 223 \mathrm{M})$. This decrease stems from the fact that the 
total number of ponds and the land required decreases. Due to the decrease in the number of pond, the AOC also decreased from \$146 M to \$131 M (Fig.5.2). Decrease in the annual operating cost prompted the unit cost, which is the annual operating cost divided by the total annual protein, decrease from $\$ 2.86 / \mathrm{kg}$ to $\$ 2.58 / \mathrm{kg}$ (Fig. 3). Since the minimum protein price is contingent on both the FCI and AOC, their decrease consequently reduced the protein price from $\$ 4.13 / \mathrm{kg}$ to $\$ 3.61 / \mathrm{kg}$ (Fig. 5.3).

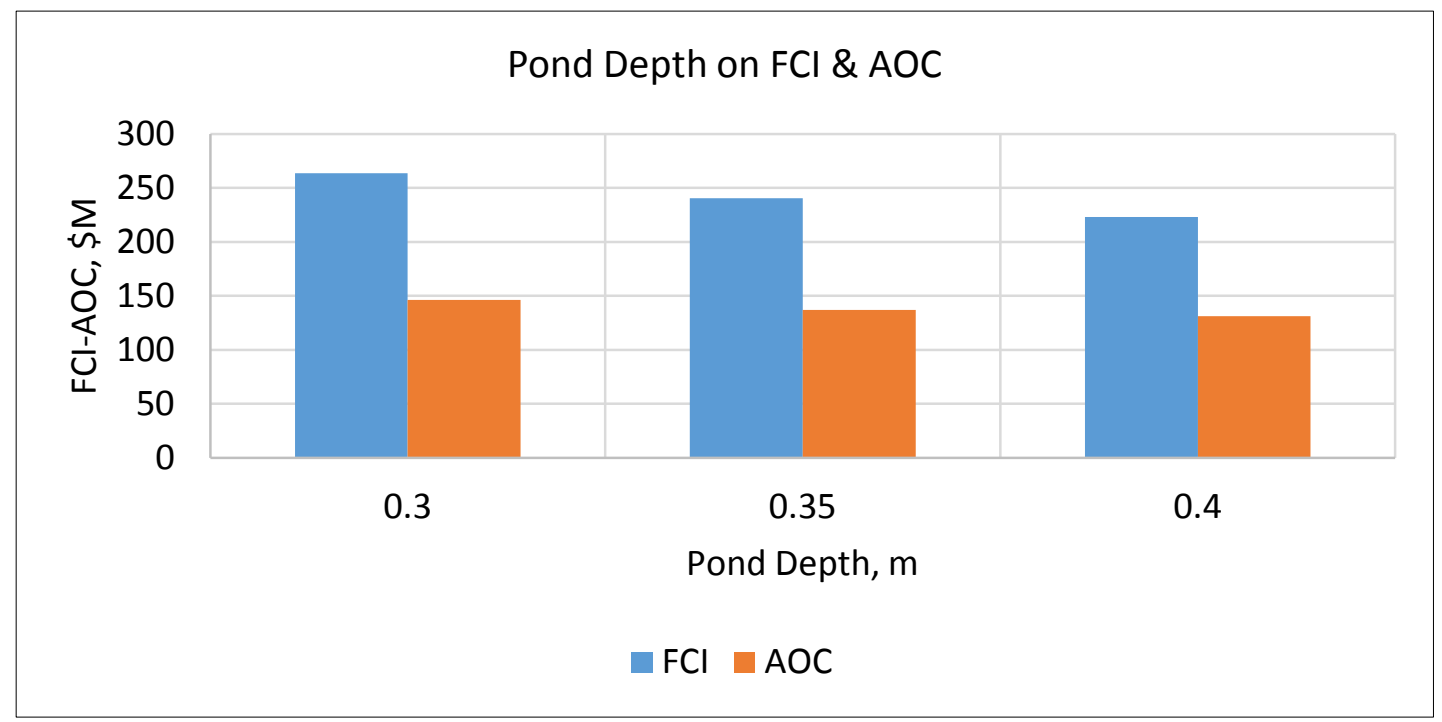

Figure 5.2 Pond Depth on FCI \& AOC

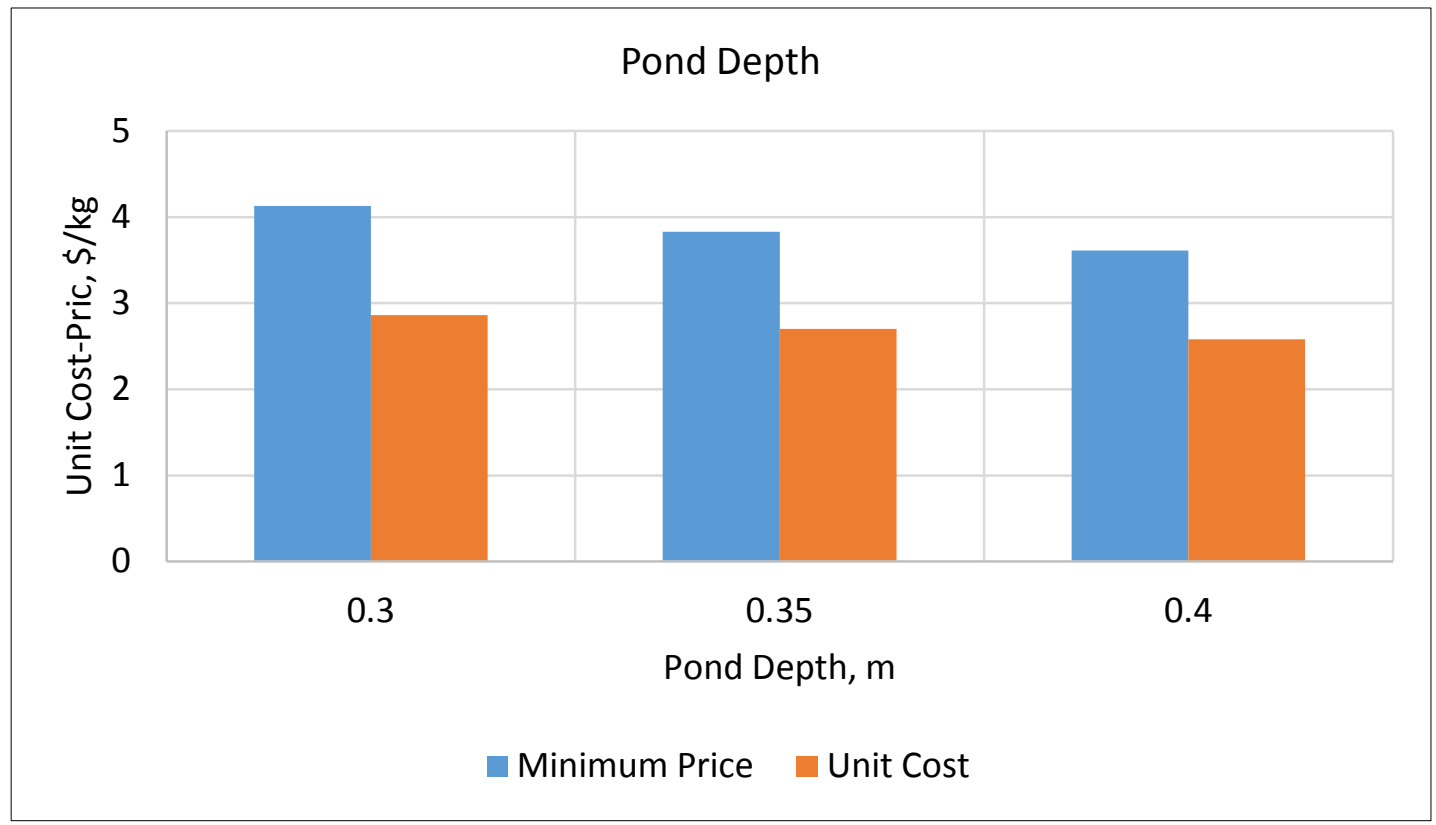

Figure 5.3 Pond Depth 


\subsection{Effect of Protein Content in the Algae}

The percent protein content in the microalgae dictates the amount of annual protein produced. The baseline protein content in the microalgae is assumed to be $54 \%$. Changing the protein from $54 \%$ to $70 \%$ increases the protein from $6.4 \mathrm{MT} / \mathrm{h}$ to 8.34 $\mathrm{MT} / \mathrm{h}$, which in turn decreases the protein price from $\$ 4.13 / \mathrm{kg}$ to $\$ 3.18 / \mathrm{kg}$ (Fig 5.4). Increase in the protein content decreases the total amount of solids generated during flash hydrolysis. This consequently reduces the number of filters required for filtration prior to ultrafiltration. Moreover, the number of ultrafilters also decreases due high protein concentration gradient across the membrane. These reductions in equipment slightly decrease the both FCI (from \$264 M to \$262 M) and AOC (from \$146 M to \$145 million) as the protein content in the microalgae increases. The unit cost eventually reduces from $\$ 2.86 / \mathrm{kg}$ to $\$ 2.20 / \mathrm{kg}$ (Fig 5.4). Moreover, the annualized cost decreased from \$180M to \$179M.

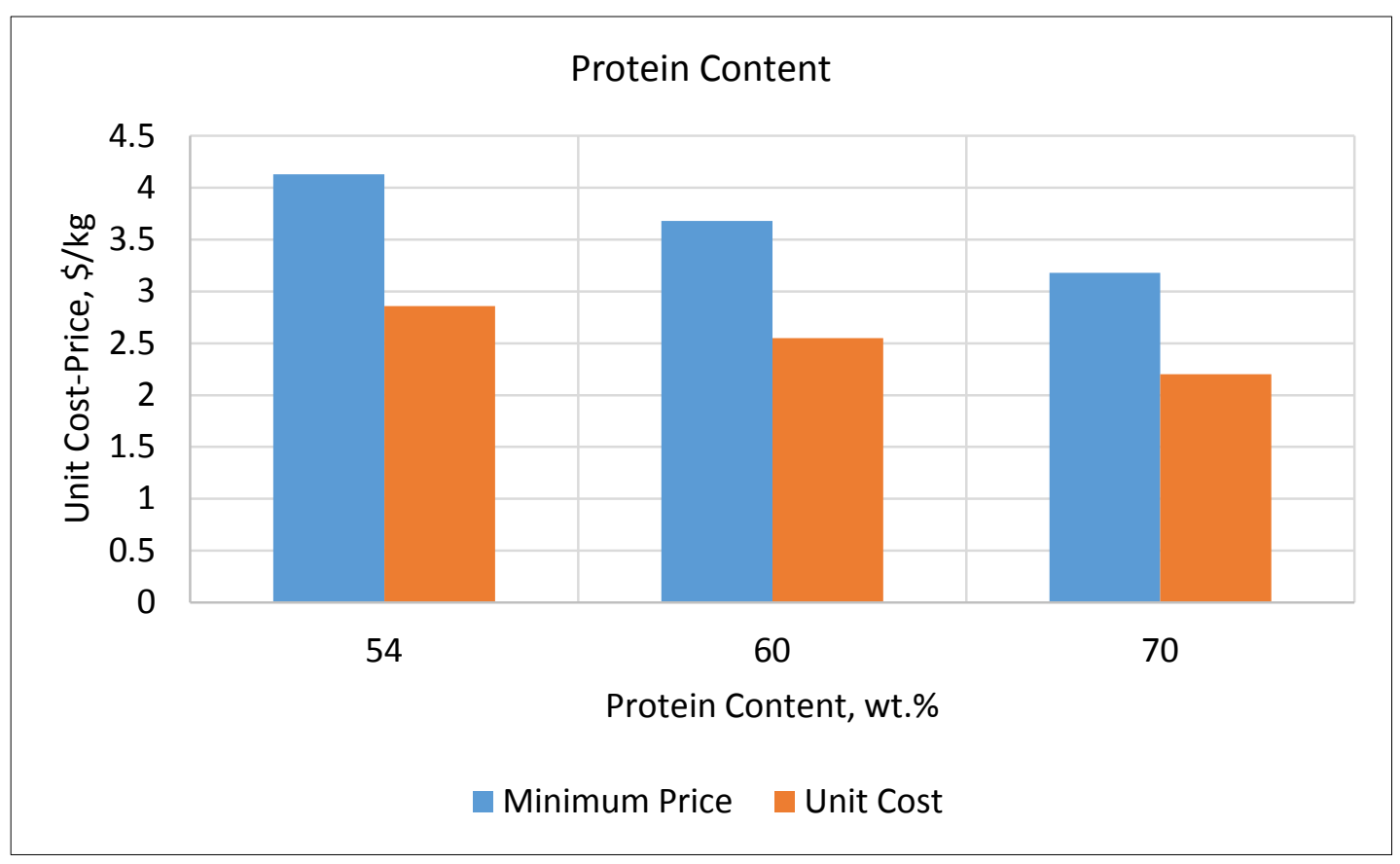

Figure 5.4 Protein Content 


\subsection{Effect of Algae Productivity}

Davis et al. employed algae productivity $25 \mathrm{~g} / \mathrm{m}^{2} /$ day as the baseline in their simulation of techno-economic analysis of autotrophic microalgae for fuel production. Rogers et al. also use a value of $15 \mathrm{~g} / \mathrm{m}^{2} /$ day in simulating a critical analysis of paddlewheel-driven raceway ponds for algal biofuel production at commercial scales. In this work the baseline algae productivity was assumed to $15 \mathrm{~g} / \mathrm{m}^{2} /$ day. This value affects the concentration of the biomass a given pond for a given area. Varying the algae productivity from $10 \mathrm{~g} / \mathrm{m}^{2} /$ day to $25 \mathrm{~g} / \mathrm{m}^{2} /$ day increases the algae biomass from 6.4 $\mathrm{MT} / \mathrm{h}$ to $38.7 \mathrm{MT} / \mathrm{h}$. This increase moved the minimum protein price from $\$ 4.13 / \mathrm{kg}$ to $\$ 1.50 / \mathrm{kg}$ while the unit cost of protein changed from $\$ 2.86 / \mathrm{kg}$ to $\$ 1.04 / \mathrm{kg}$ (Fig. 5.5). The increase in algae productivity does not affect FCI and AOC since this factor describes the microbial growth rate and not the need for additional area. Microbial growth rate can be improved by employing genetically modified culture. This also depends on the location of the pond where radiant energy is present 12 hours/day.

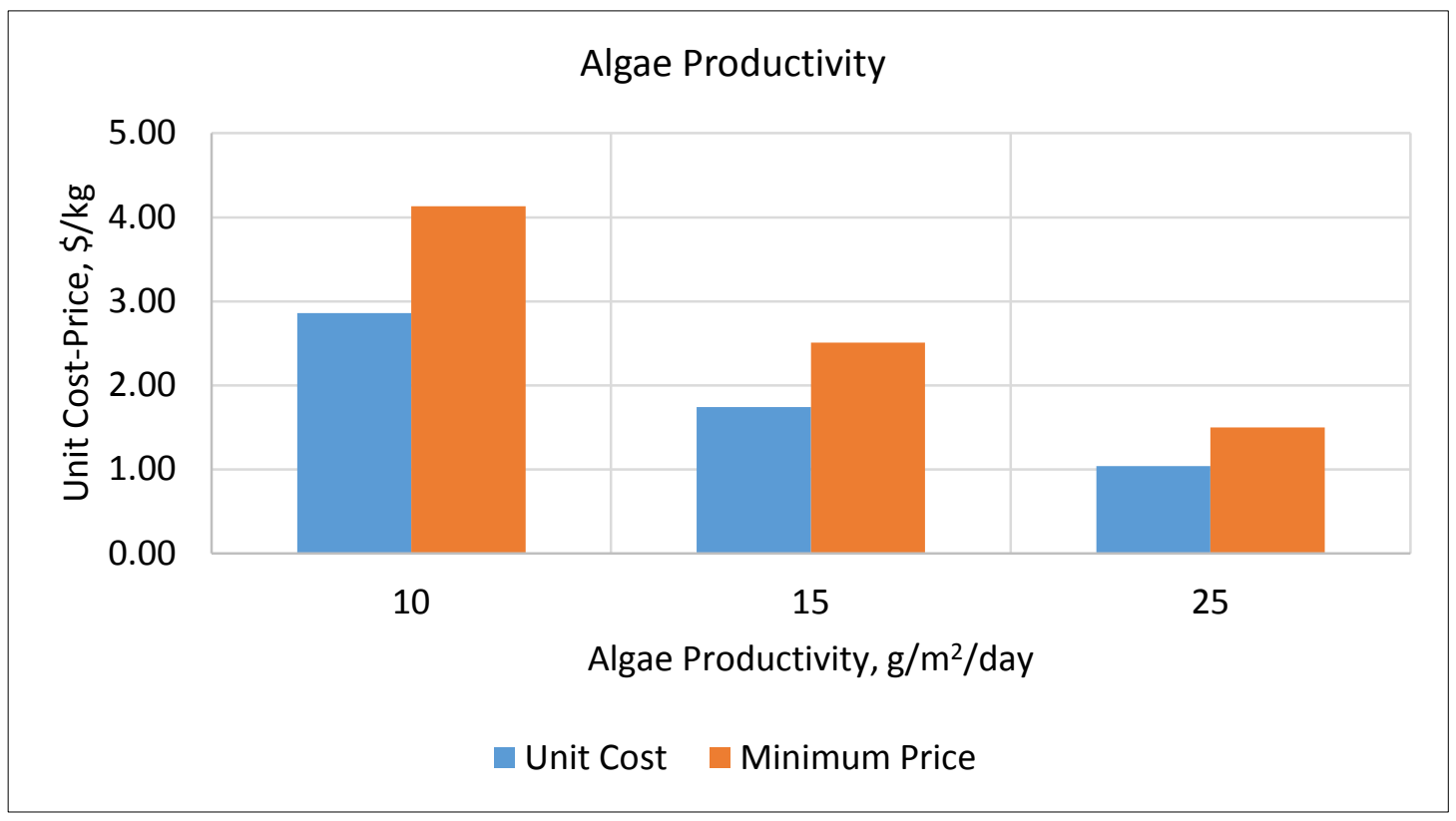

Figure 5.5 Algae Productivity 


\subsection{Effect of Water Recycle}

Water recycle in the algae industry is highly indispensable practice. In this work, without water recycle, the annual amount of water required would be 127 million gallons per day (MGD) (\$2.1 million per year), which is approximately $1.4 \%$ of the AOC. However, with incorporation of recycling strategy, the annual water utilized was approximately 4.2 MGD (\$0.07 million per year), which represents 97\% reduction in the cost of annual water use. In this work, it is assumed that $98 \%$ of the water is recycled. Testing the sensitivity of percent water recycle on the AOC did not show any significant change. This is buttressed by the fact that the annual cost of water contribution to the AOC is merely $1 \%$. Davis et al. reported that varying the percent water recycle from $80-100 \%$ did not change the unit cost and minimum price of the algae. Fig. 5.6 depicts the change in water use as the percent recycle changes.

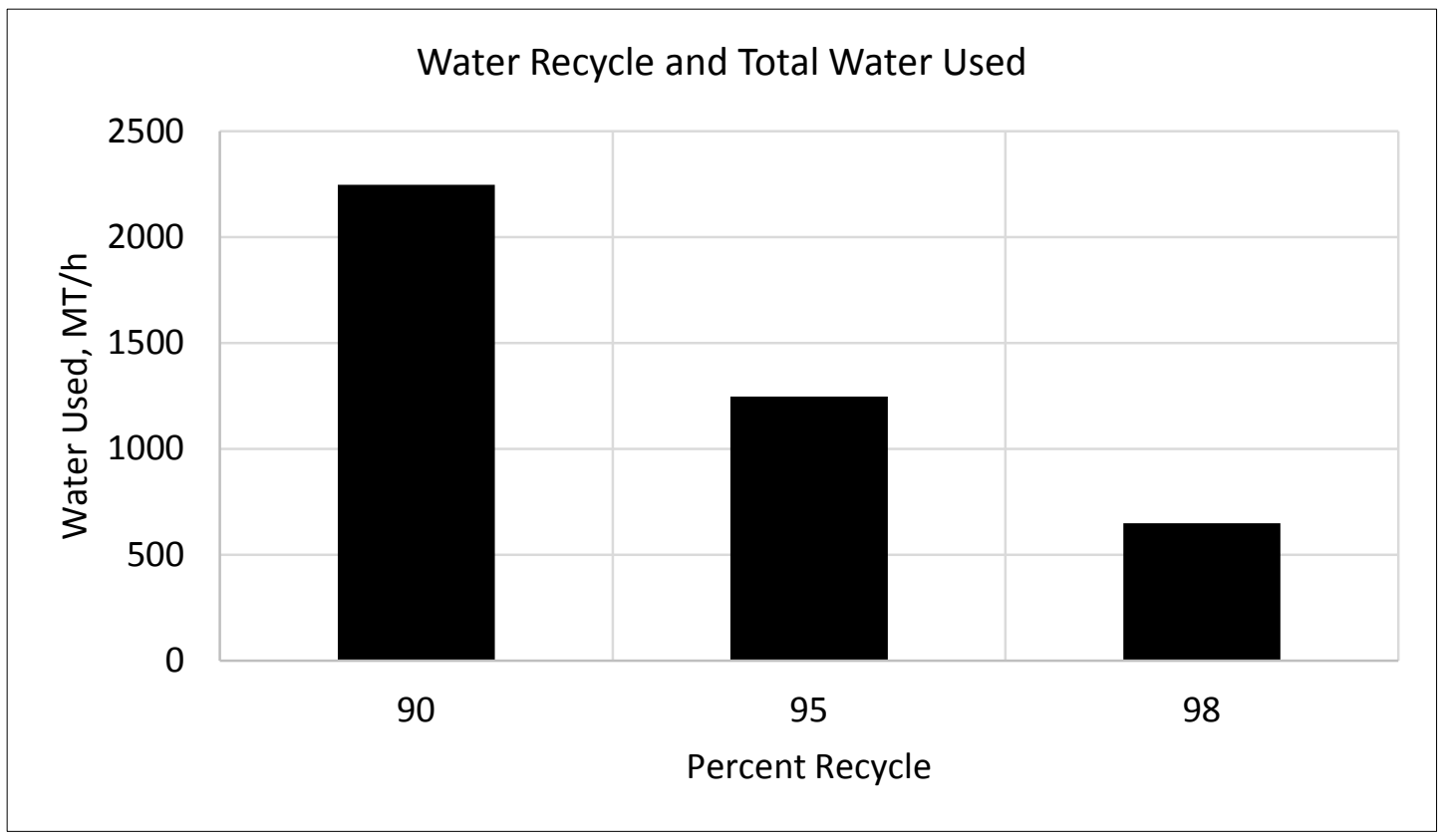

Figure 5.6 Water Recycle and Total Water Used 


\subsection{Effect of Algae Slurry}

In flash hydrolysis, the more the water content of the slurry the more energy required to pump, and the more the annual operation cost for a specific production capacity. In this work, the simulation was done using 20 wt.\% of algae slurry. Dote et al and Minowa et al. published the first reports of hydrothermal liquefaction of microalgae using a batch reactor with high feed concentration dry matter algae mass, 50 wt.\% and 78.4 wt.\%, respectively. However, pumping these slurries through a continuous reactor is highly impractical due to flowability issues.

In this study, decreasing the percent weight of the algae slurry increases the FCI and AOC due to the increase in the total volume of slurry with the amount of dry weight of algae being constant (14 MT/h i.e. the baseline). Moreover, the total mass of water increases from $649 \mathrm{MT} / \mathrm{h}$ to $866 \mathrm{MT} / \mathrm{h}$. Furthermore, the number of filters, ultrafilter, anaerobic digesters, pumps, etc. increases when the percent algae in the slurry decreases from 20 to $5 \%$. Increase in the number of equipment increases the amount of total power consumed from 19.5 MW to $22 \mathrm{MW}$. Furthermore, the total water consumption increases by 25\% (i.e. $649 \mathrm{MT} / \mathrm{h}$ to $866 \mathrm{MT} / \mathrm{h}$ ). As a result, the FCI increased from \$264 million to \$481 million while AOC increased from \$146 million to $\$ 301$ million (Fig.5.7). Consequently, the unit cost and minimum prices increased from $\$ 2.86-\$ 5.94$ and $\$ 4.13$ to $\$ 8.34$ respectively (Fig. 5.8). 


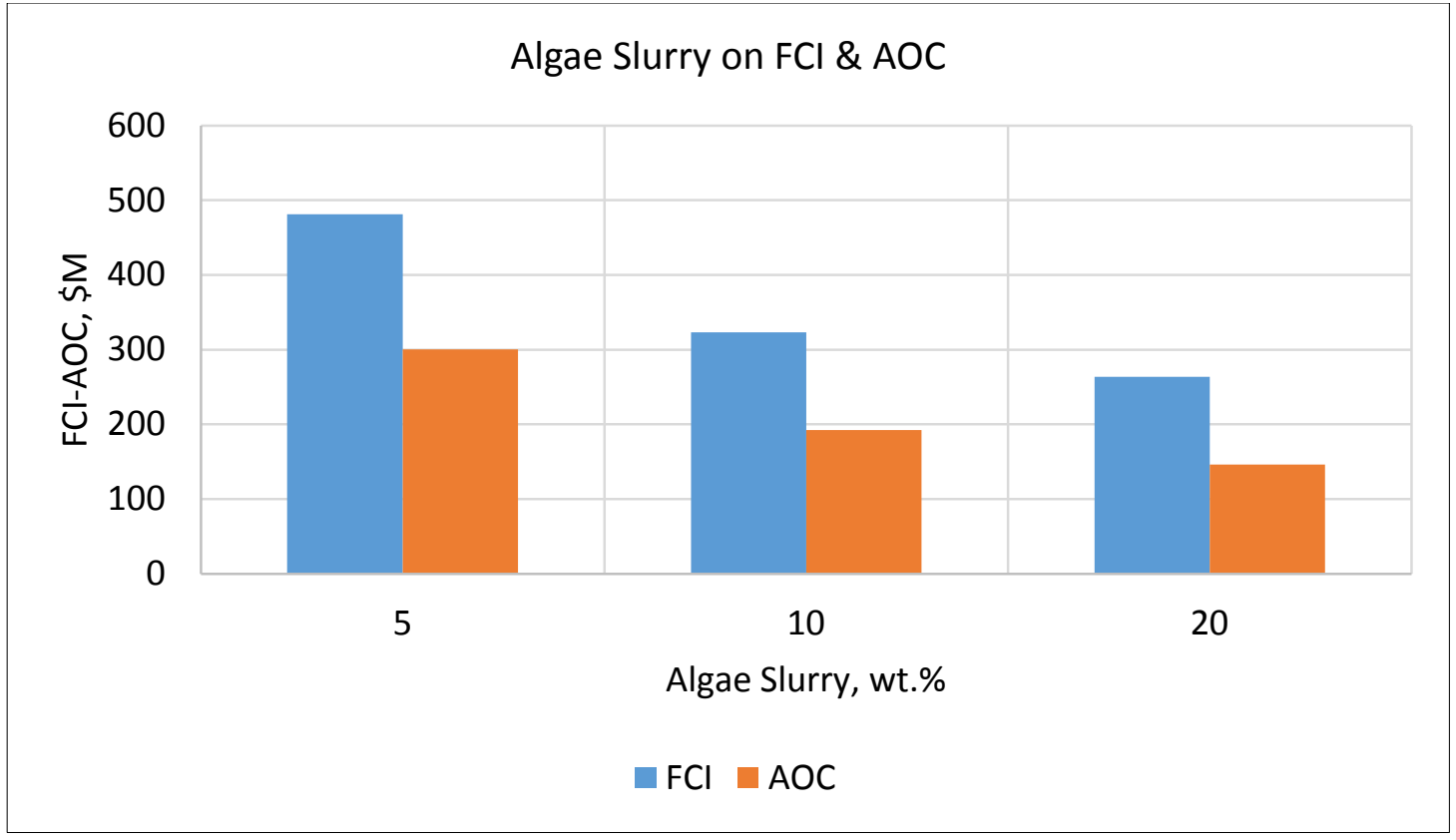

Figure 5.7 Algae Slurry on FCI \&AOC

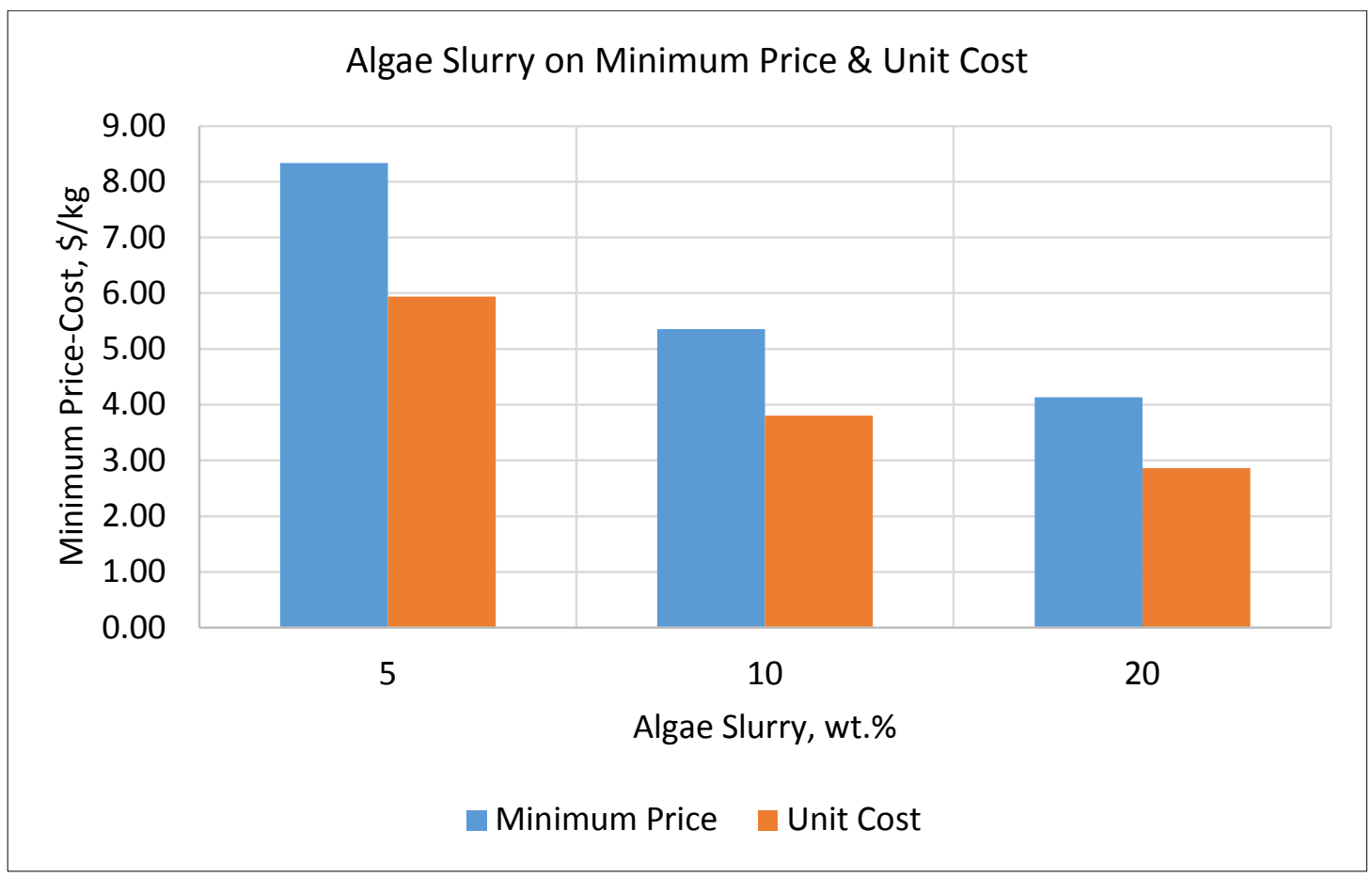

Figure 5.8 Algae Slurry on Minimum Price-Unit Cost 


\subsection{Effect of Project life}

The life of a project is crucial as far as recouping of the FCI is concerned. Moreover, it is well-advised to reduce the project life in profitability analysis so as to offset any risk of inflation. Increasing or decreasing the project life affects the minimum product price and the annualized capital investment. The baseline project life in this work is assumed to be 15 years. Changing the project life from 10 to 20 years decreases the minimum product price from $\$ 4.75$ to $\$ 3.90$ while the annualized cost decreases from \$188 M to \$176 M (Fig.5. 9 and 5.10).

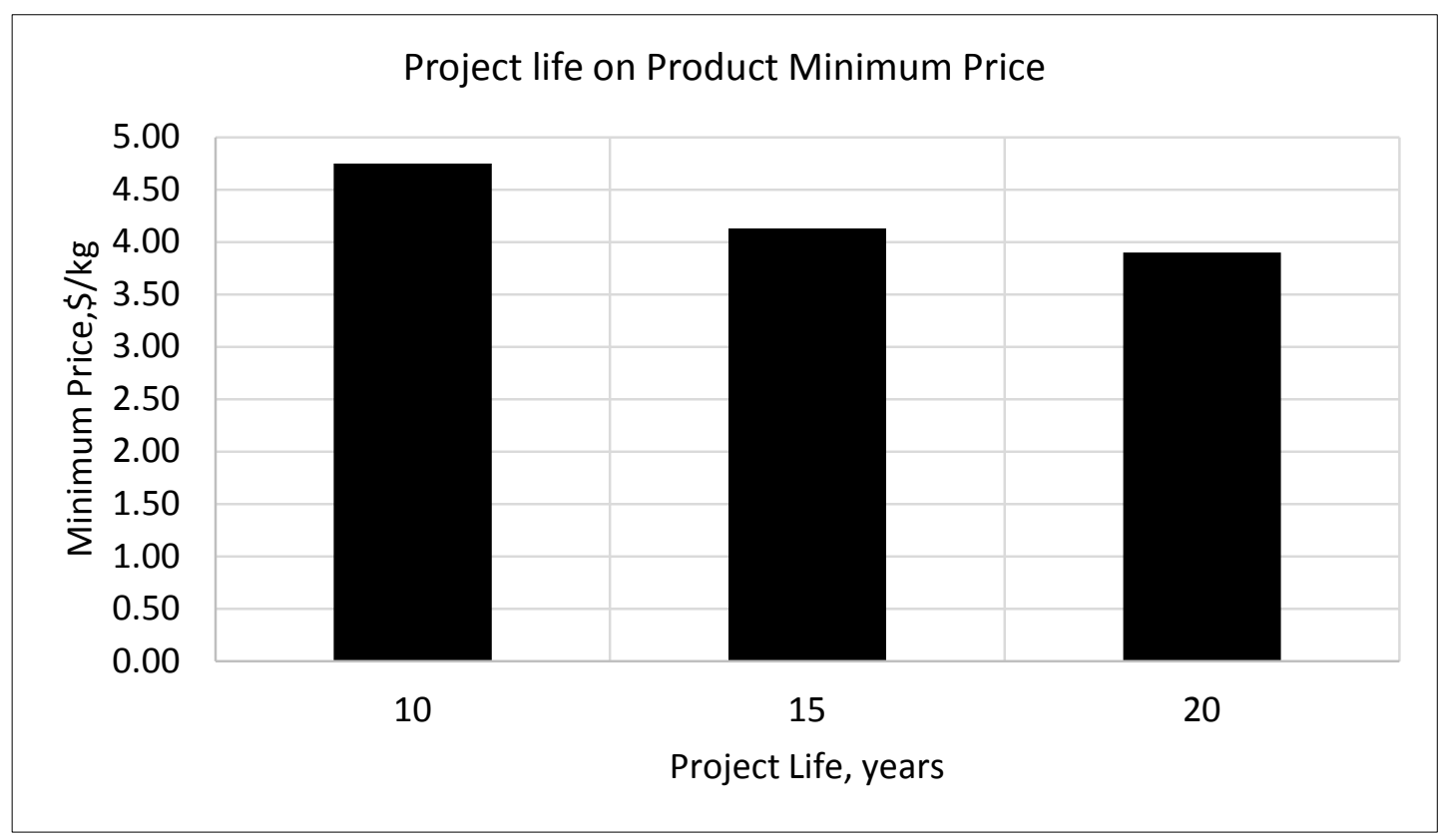

Figure 5.9 Project life Product Minimum Price 


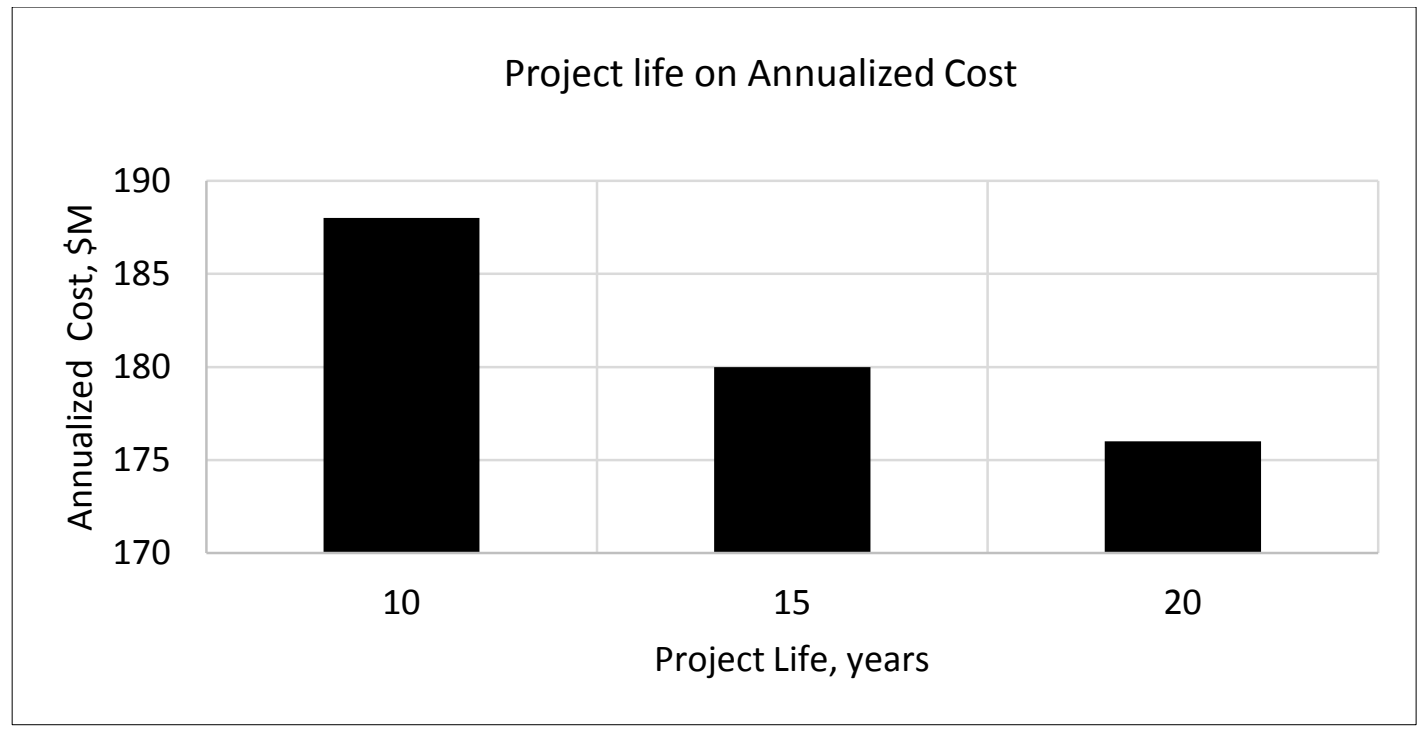

Figure 5.10 Project Life on Annualized Cost

\subsection{Effect of Discount Rate}

Another important parameter of interest in this work is the discount rate of the interest rate. The baseline interest rate in this work is assumed to be $10 \%$. Varying the interest rate from $7-12 \%$ increases the minimum product price from $\$ 3.87$ to $\$ 4.33$ while the annualized capital investment jumps from \$174 M to \$183 M (fig. 5.11 and $5.12)$.

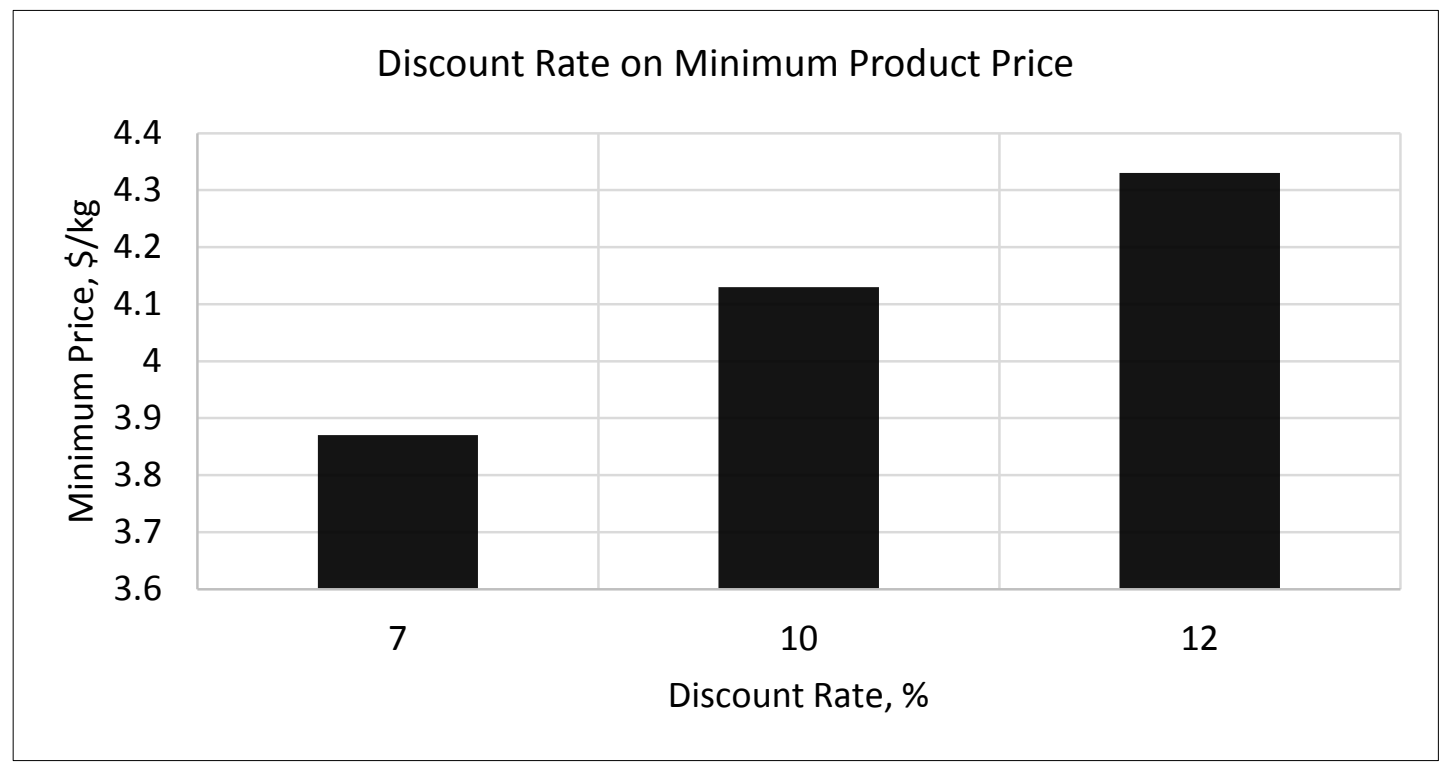

Figure 5.11 Discount rate on minimum Product price 


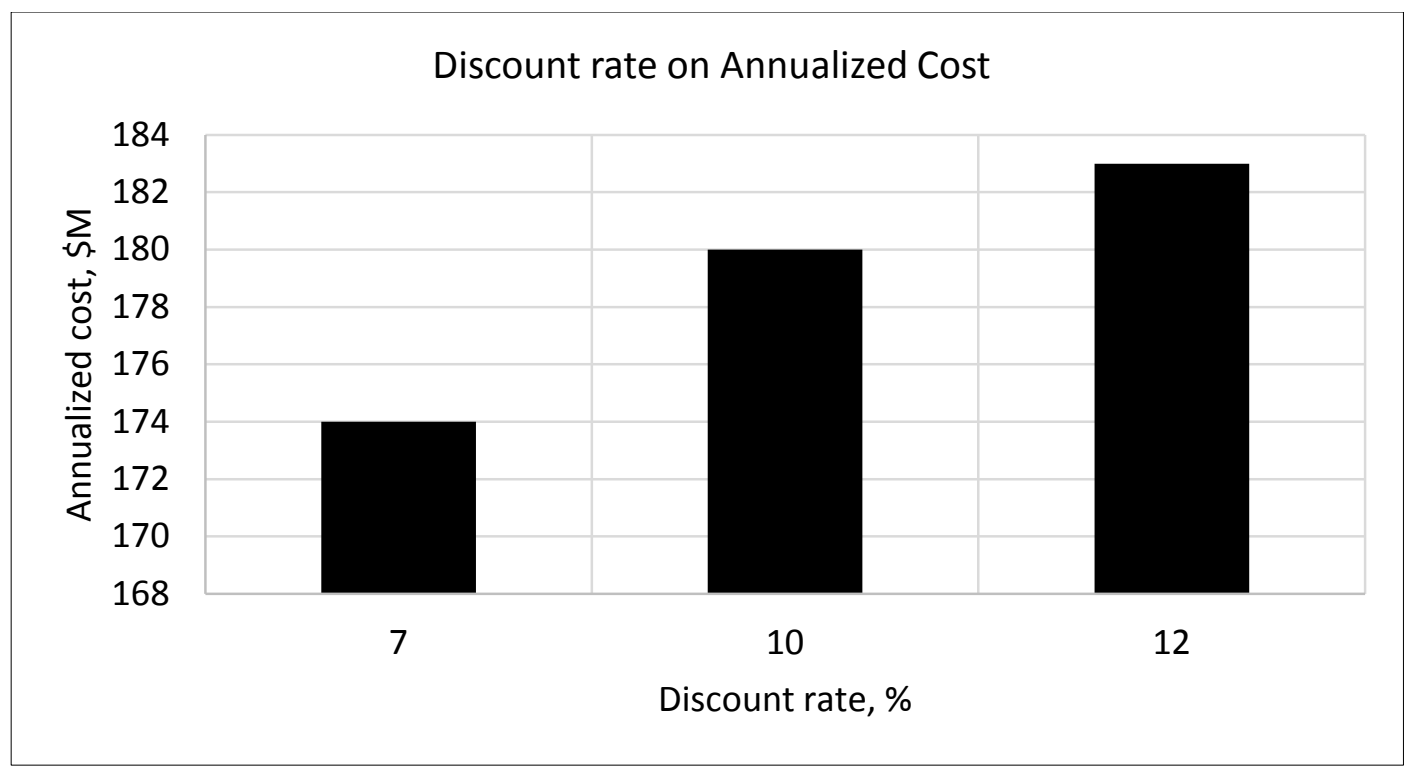

Figure 5.12 Discount rate on Annualized Cost

\subsection{Effect of Product Price}

The viability of protein concentrate production from microalgae by flash hydrolysis was assessed by looking at the net present value (NPV), internal rate of return (IRR) and the payback period (PBP) based on the product prices. It is obvious that product prices from $\$ 4.13 / \mathrm{kg}-\$ 6.00 / \mathrm{kg}$ reduce the PBP from $10-3$ years at an interest rate of $10 \%$ (Fig. 5.13). This is highly attractive provided there is a limited risk in the process technology, supply and cost of raw material and market for protein concentrate. Besides, many companies prefer PBP of 3 to 5 years [El-Halwagi, 2012]. The protein price in this work can be compare to that obtained by Navarro da Silva et al. who reported R $\$ 23.70 / \mathrm{kg}$ (6.25US/kg) of 80 wt.\% whey protein concentrate.

In order to assess the viability of the project, the sensitivity of the NPV was tested via the minimum prices. It could therefore be inferred from Fig.5.14 that NPV becomes more positive with product prices climbing from $\$ 4.13$ to $\$ 6.00$ (see Table 7.1). 
Though IRR is a subjective financial parameter, its knowledge will assist stakeholders in the algae industry to make easy and sound decision. It is truism that higher product price gives higher IRR. The higher the IRR the more attractive the enterprise.

Fig. 5.15 highlights the effect of internal rate of return as product prices increase. These evaluations are based on 10\% interest rate, 40\% tax rate and 100\% debt financing.

Table 9 Effect on product price on NPV, PBP, and IRR

\begin{tabular}{llll}
\hline $\begin{array}{l}\text { Protein Price } \\
\$ / \mathrm{kg}\end{array}$ & NPV & PBP & $\begin{array}{l}\text { IRR } \\
\%\end{array}$ \\
\hline 4.13 & Million Dollars & Years & 25 \\
4.50 & 0.0 & 9.8 & 30 \\
5.00 & 57 & 7.1 & 36 \\
5.50 & 134 & 5.1 & 42 \\
6.00 & 212 & 4.1 & 48 \\
\hline
\end{tabular}

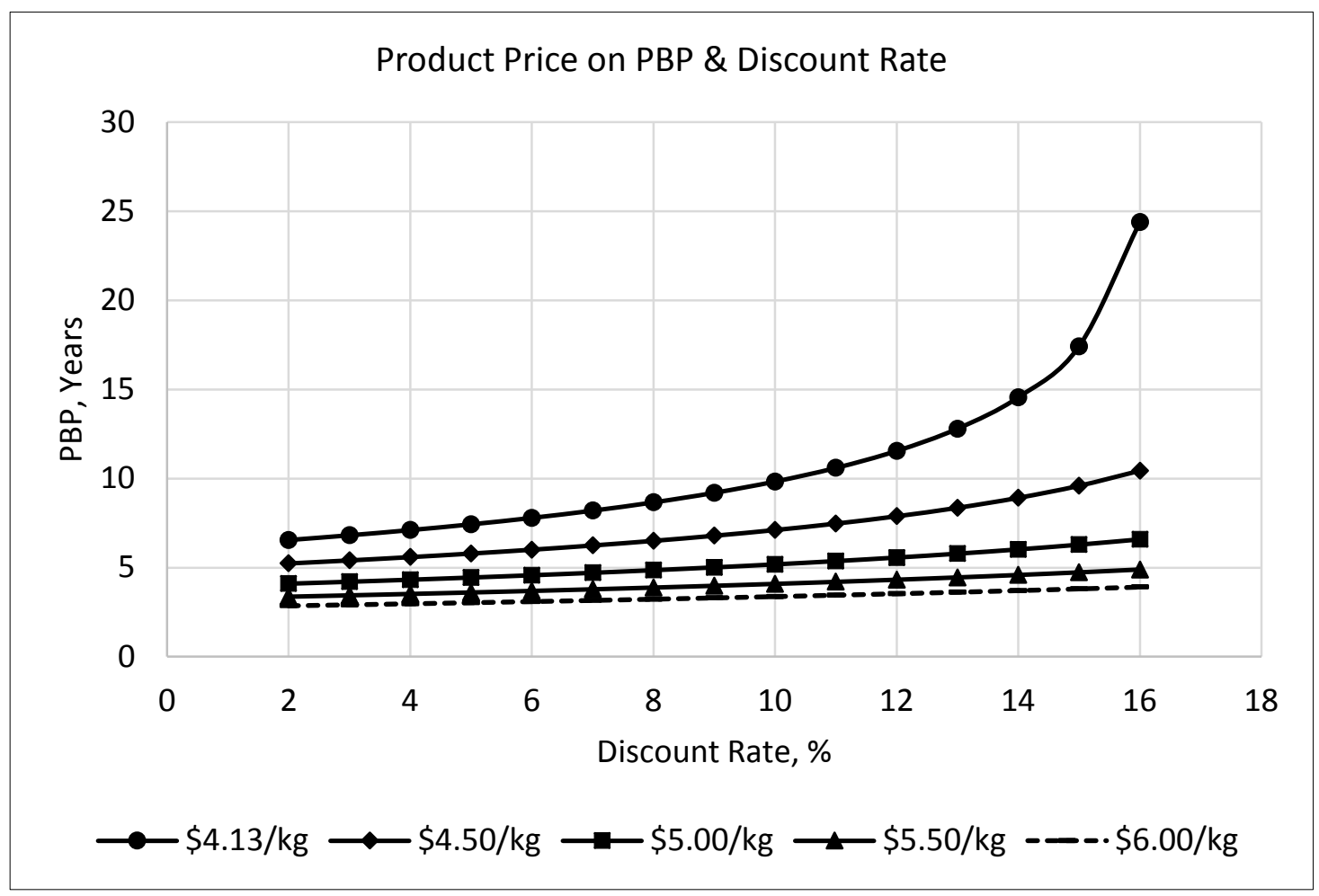

Figure 5.13 Product Price on PBP \& Discount Rate 


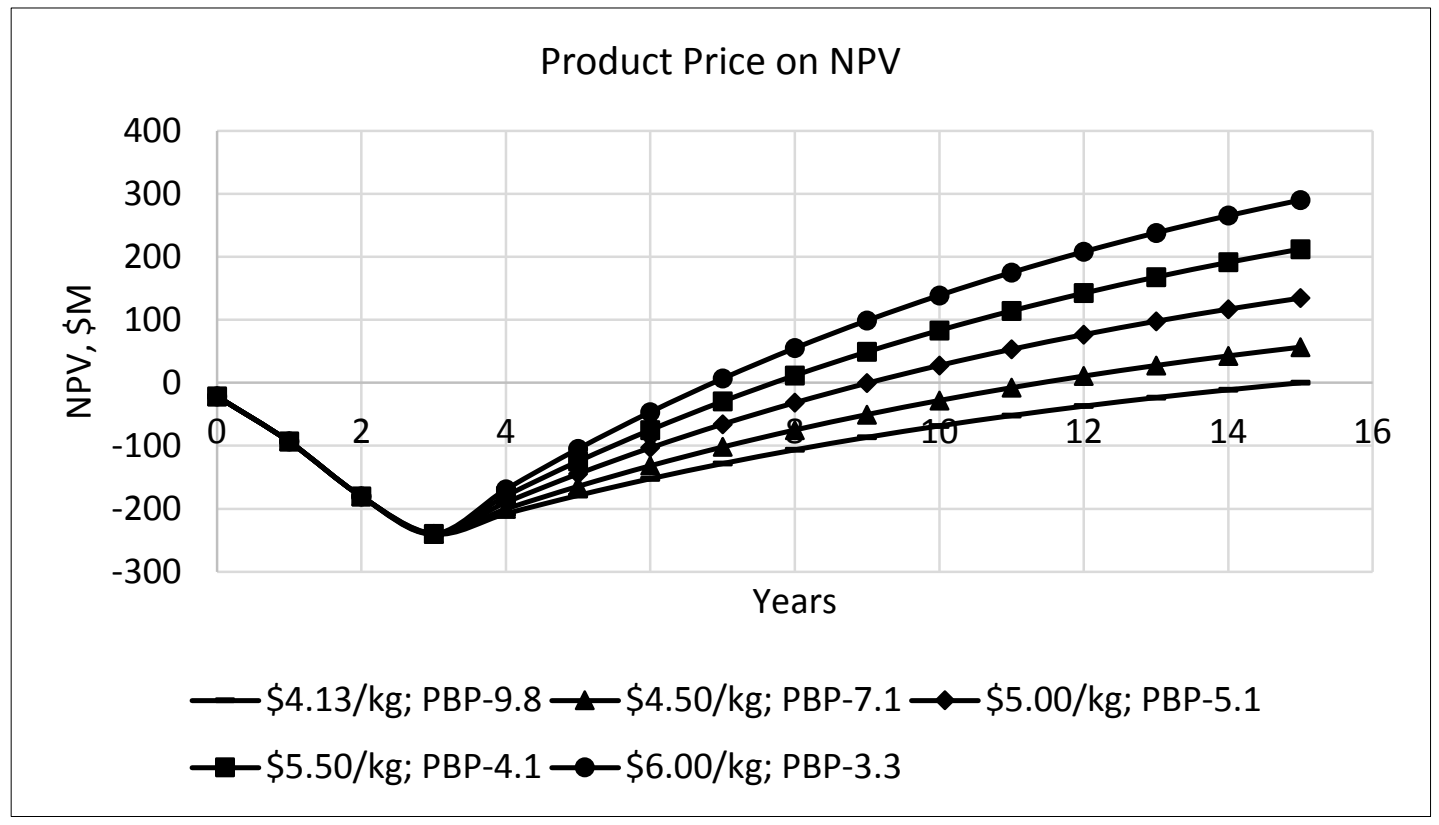

Figure 7.14 Product Price on NPV

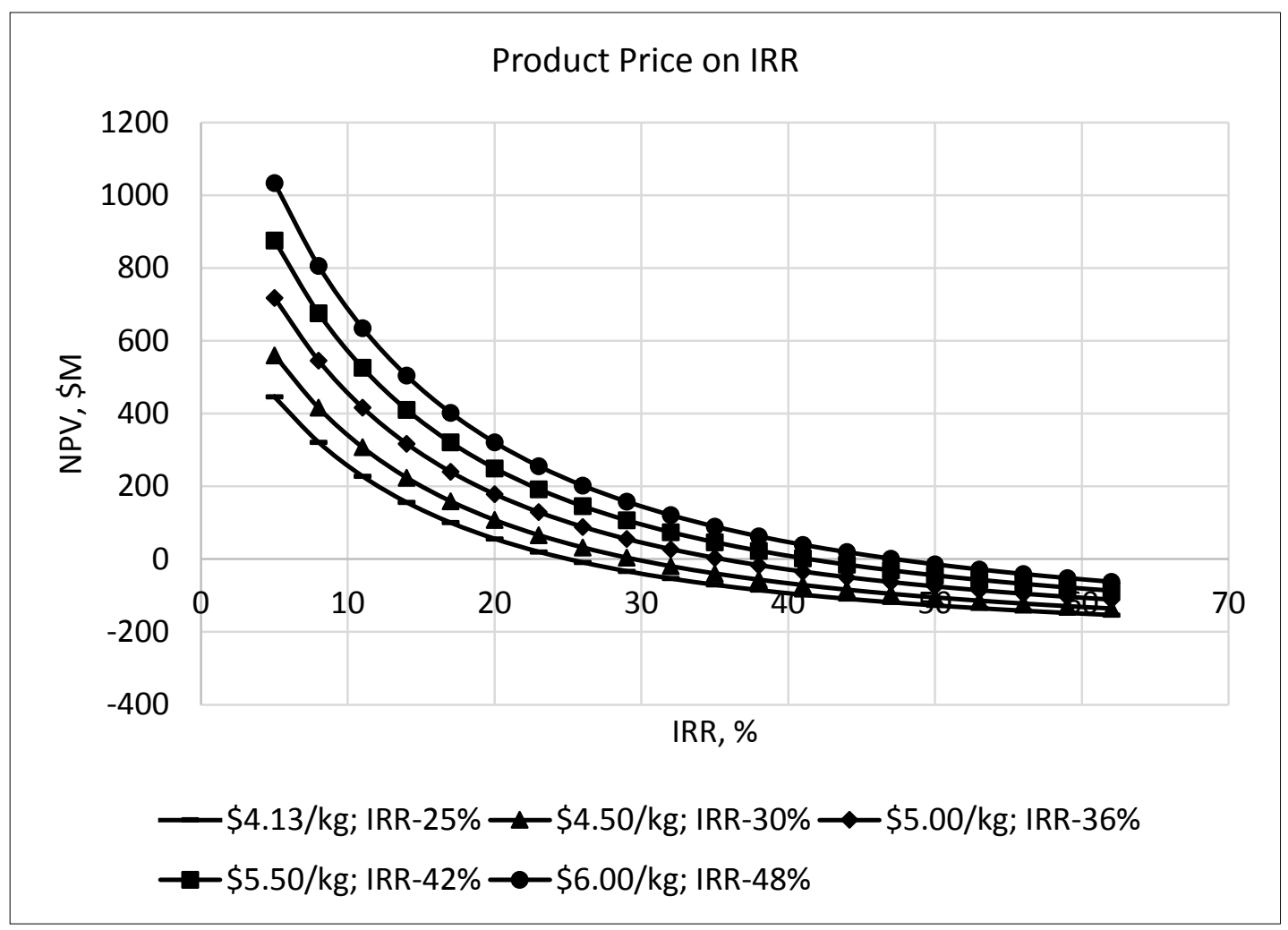

Figure 5.15 Product Price on IRR 


\subsection{Major Drivers of Unit Cost and Price}

Figures 5.16 and 5.17 depict the summary of sensitivity of unit cost and price of protein concentrate to the aforementioned factors in the work. The only factors not discussed in the preceding section are the effect of pond covering, pond liner, paddle wheel energy consumption, and $\mathrm{CO}_{2}$ and flue gas.

It is assumed that high density polyethylene (HDPE) can be used a pond cover to reduce evaporation of water from the raceway pond. However, foregoing pond covering reduces the FCI, AOC, and annualized cost (AC) to \$233 million, \$138 million and \$168 million respectively, which resulted in unit cost and unit price reduction of $\$ 15$ and $\$ 30$ respectively.

To enhance photosynthetic efficiency of a raceway pond, there is the need to incorporate paddlewheel to agitate the algae culture, and expose them to the necessary radiant energy. Lundquist et al. reported that absence of light for the algae culture over the night can result in biomass loss of 25\%. Mixing and agitation the pond demand huge amount of energy. In this work, $0.73 \mathrm{~W} / \mathrm{m}^{2}$ was used as published by Rogers et al. However, reducing this value to $0.22 \mathrm{~W} / \mathrm{m}^{2}$ reduced the FCI and AOC to \$ 262.5 million and \$134 million respectively, which consequently reduced the unit cost and unit price equally by $\$ 22$.

Pond liners play crucial role in raceway pond by preventing pond contamination or leakage. These liners could be clay, concrete, HDPE, etc. However, due to cracks and seismic activities, HDPE is preferred to clay and concrete [Roger et al., 2013]. In this work the cost of lining all the ponds (19138) amounts to \$5.3 million (2\% of FCI). Without lining the pond, the FCI dropped to \$243.4 million thereby reducing the unit price and cost by $\$ 20$ and $\$ 10$ respectively. 
Supplying $\mathrm{CO}_{2}$ to the microalgae via the flue gas has the advantage reducing global warming from power plants. However, in this work it is evident that using pure $\mathrm{CO}_{2}$ is more economically friendly than employing flue gas. With the current $\mathrm{CO}_{2}$ price of $\$ 40 /$ ton, the FCI and AOC of this work reduced to \$253 million and \$139 million respectively. It could be seen that the unit cost and prices decreased by $\$ 12$ and $\$ 16$ respectively. However, forgoing flue as a source of $\mathrm{CO}_{2}$ supply also offsets in situ major power supply to the plant. Nevertheless, minor power (3.2 MW) supply can be produced from the approximately $2 \mathrm{MT} / \mathrm{h}$ methane from the anaerobic reactor. This minor power supply represents $16 \%$ of the required total power for the whole process. This means the rest of the power should be purchased from outside the plant.

Furthermore, it is evident that algae productivity and slurry to the $\mathrm{FH}$ have the most remarkable effect on both unit cost and prices of the protein concentrate production.

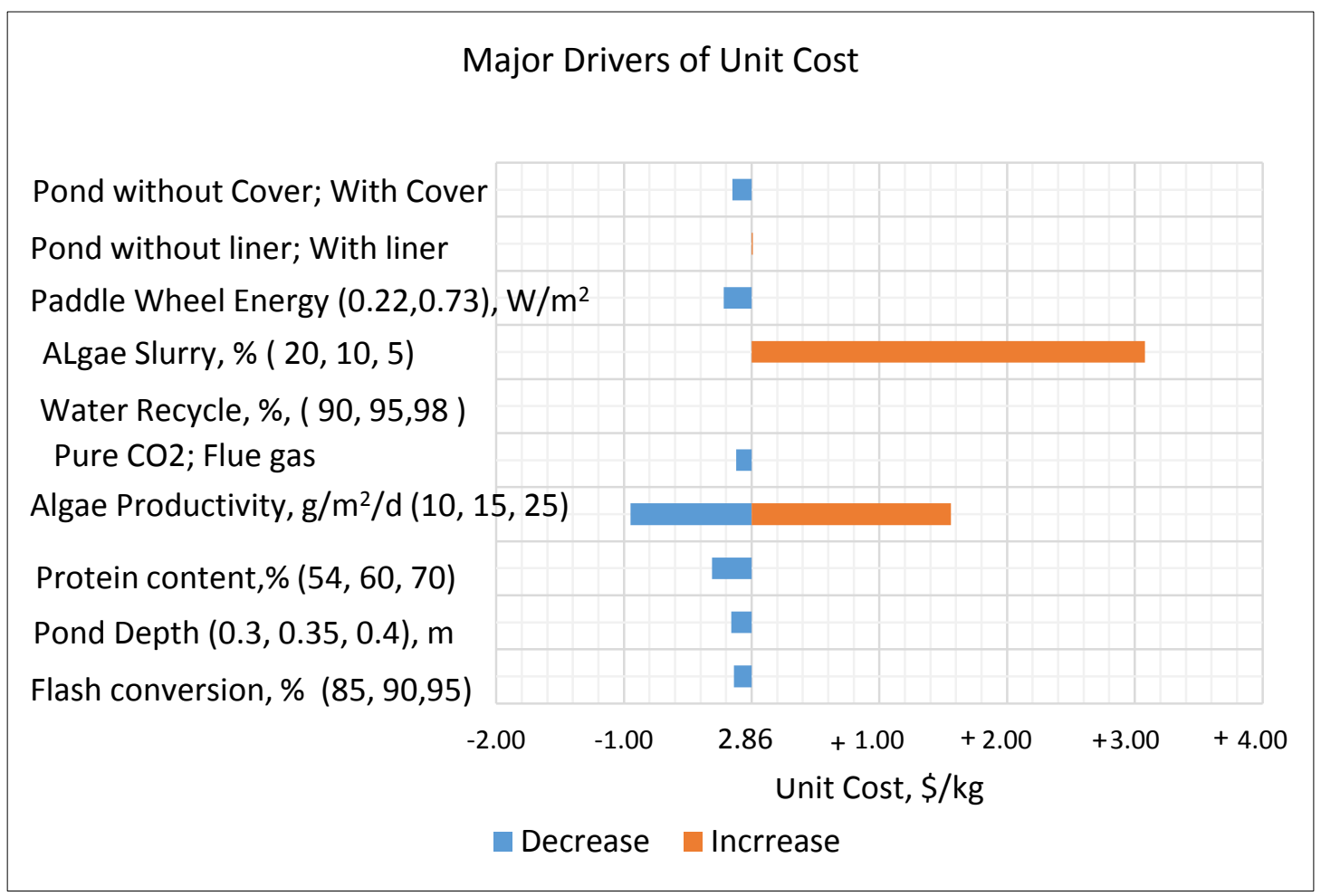

Figure 5.16 Major Drivers of Unit Cost 


\section{Major Drivers of Protein Price}

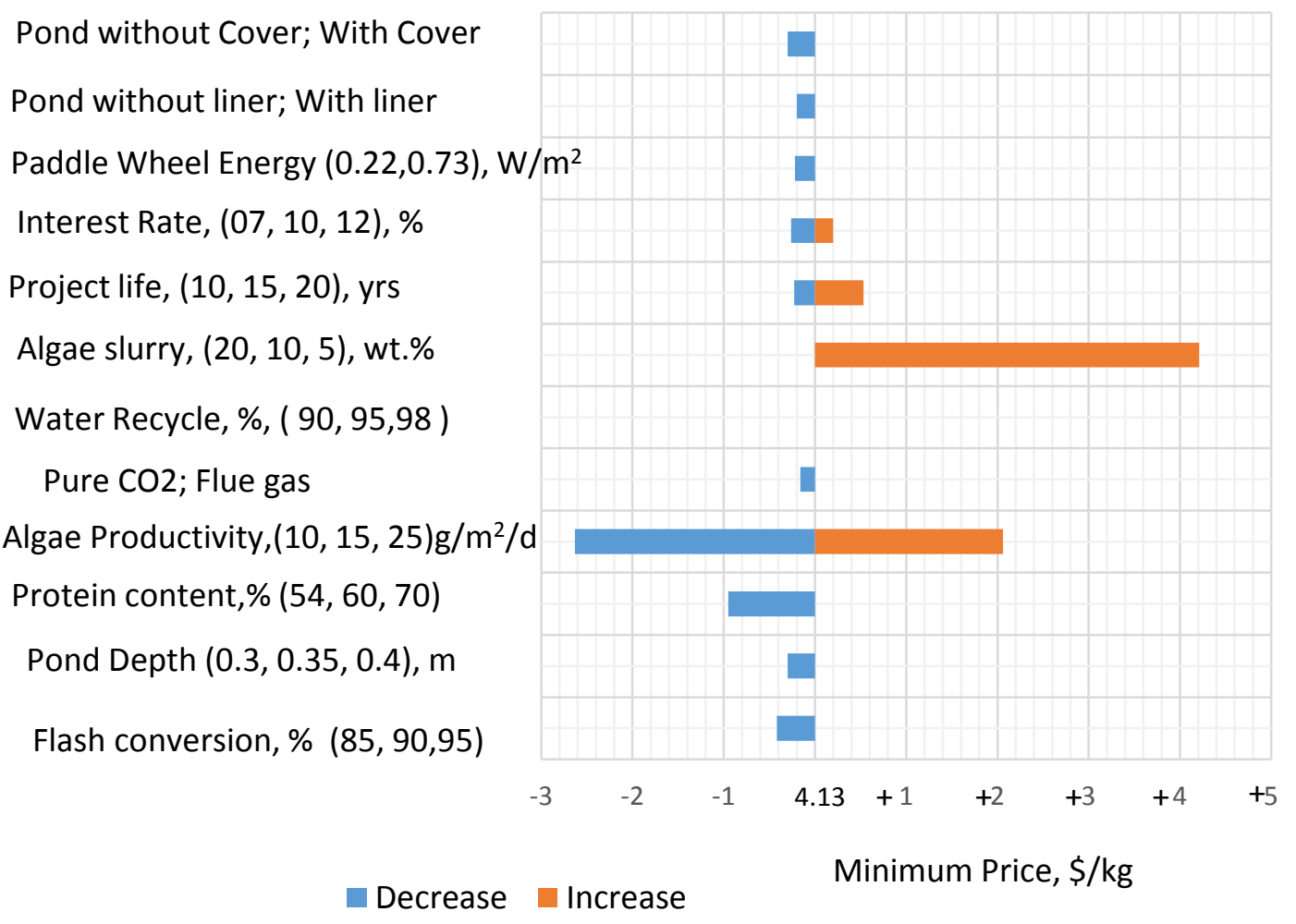

Figure 5.17 Major Drivers of the Protein Price

\subsection{Effect of Plant Capacity}

Most industrial enterprises capitalize on the economy of scale i.e. the bigger the better. Conversely, it does not work well in the present work. Under normal circumstances, increasing the number of barrels of protein concentrate produced decreases the selling price. However, the change in prices of protein is not remarkable above capacity of $160 \mathrm{MT} /$ day as compared to below 160 MT/day (Fig. 5.18). Moreover, production capacities above 160 MT/day, require huge capital input that could scare investors (Fig. 5.19). Table A2 in the appendix delineates results of capacity impact on the salient economic inputs and output from this work. 


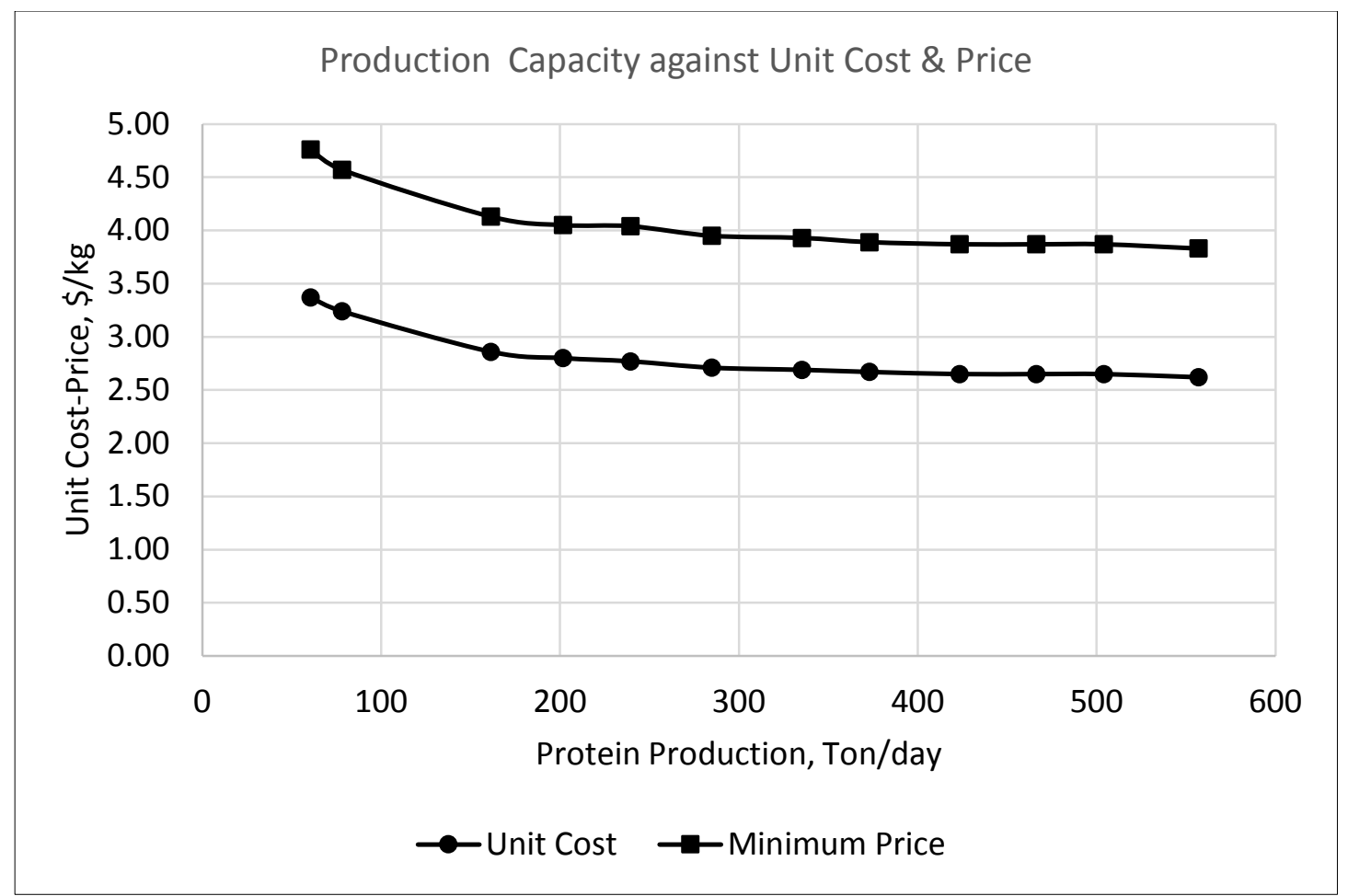

Figure 5.18 Production Capacity against Unit Cost \&Price

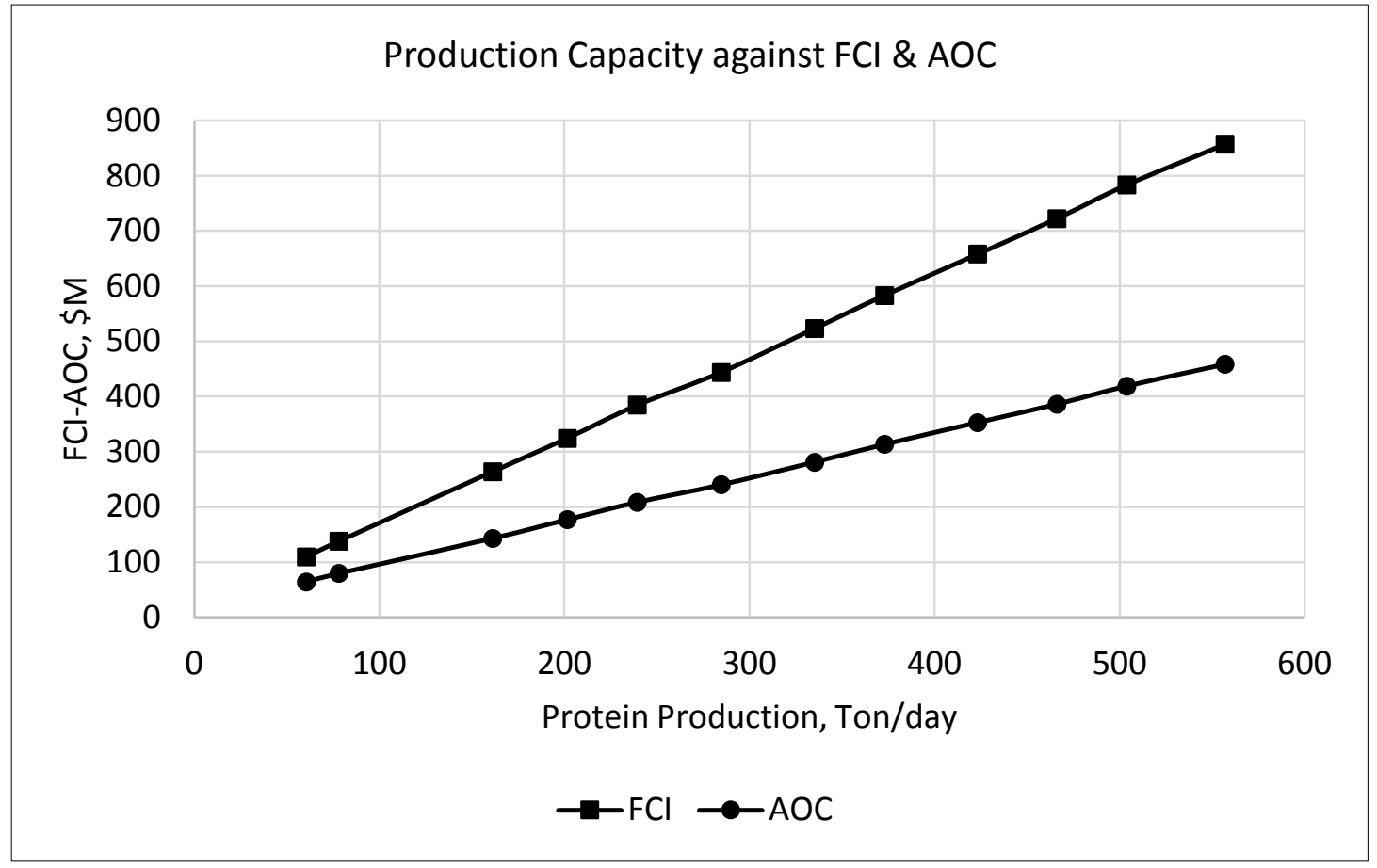

Figure 5.19 Production Capacity against FCI \& AOC 


\section{CONCLUSIONS}

This work has focused on the technical and economic assessment of 95 wt.\% protein concentrate (food and pharmaceutical grade) production from microalgae. Data used is based on the previous work done at the Old Dominion Algae Laboratory. Additional data concerning protein production from microalgae has been generated to assist stakeholders in the algae industry to make meaningful technical and economic decisions. A baseline capacity of $160 \mathrm{MT} /$ day of protein concentrate was employed in developing this model.

However, there are hurdles in the scalability of this model to a full-scale operation looking at the huge FCI and AOC. One of the obstacles in this work is the huge amount of freshwater required to grow the algae. To embark upon this enterprise, there is the need to locate the plant near places with abundance of water. The use of brackish or saline water, which is more abundant, has been successful in microalgae cultivation [Lee, 2001]. Wastewater has also become one the promising candidates that can be employed to grow microalgae in this kind of project. Using non-freshwater will eventually reduce the cost of water treatment and cost nutrient employed.

Not only the above-mentioned impediments are inherent in this work, but also the cost of mixing or agitating the pond for effective algal growth is real. To reduce this cost, there is the need to slope raceway ponds so the entire algae culture can flow in a fashion that will enhance utilization of radiant energy. This kind of pond design has been reported by Craags et al.1997.

Furthermore, algae productivity has most pronounced effect on the protein price, there is the need to galvanize the research and development of different strain of algae whose growth rates for protein concentrate production. 
Apart from using microalgae to produce protein concentrate, it is evident that the biofuel intermediate has the potential of supplying energy through anaerobic digestion, which supplies almost $20 \%$ of the total power requirement for the whole process.

Moreover, the percent weight of protein in microalgae play important role in economic the feasibility in this present work as it controls the yield and consequently affects the product price of protein concentrate. To enhance attractiveness of this work, more research and development should be geared towards the cultivation of high proteinaceous microalgae.

Though ultrafiltration, a membrane separation process, contributes almost $40 \%$ of the total energy demand in this work, it is more promising in producing protein concentrate. 


\section{REFERENCE}

[1] Acién FG, Ferna'ndez JM, Maga'n JJ, Molina E. Production cost of a real microalgae production plant and strategies to reduce it. J. Biotechnol Adv 2012.

[2] Alibaba Group Holding Limited. 15 November 2015. [http://www.alibaba.com/trade/search?fsb=y\&IndexArea=product_en\&CatId=\&S earchText=whey+protein+powder]

[3] Amazon. 15 November 2015.

[http://www.amazon.com/s/ref=nb_sb_ss_i_1_4?url=searchalias\%3Daps\&fieldke ywords=whey+protein+powder\&sprefix=Whey\%2 aps\%2C205]

[4] Amer, L., Adhikari, B., Pellegrino, J., 2011. Technoeconomic analysis of five microalgae-tobiofuels processes of varying complexity. Bioresour. Technol. 102, 9350-9359.

[5] Balasubramanian, Sundar; James D. Allen, Akanksha Kanitkar, Dorin Boldor. 2011. Oil extraction from Scenedesmus obliquus using a continuous microwave system - design, optimization, and quality characterization. Bioresource Technology 102 (2011) 3396-3403.

[6] Becker, E.W. 2006. Micro-algae as a source of protein. Journal of Biotechnology Advances 25 (2007) 207-210.

[7] Benemann, J., 2013. Microalgae for biofuels and animal feeds. Energies 6, $5869-5886$.

[8] Biller P, Ross AB. Potential yields and properties of oil from the hydrothermal liquefaction of microalgae with different biochemical content. Bioresour Technol 2011; 102: 215-25.

[9] Borowitzka, M.A., 1999. Commercial production of microalgae: ponds, tanks, tubes and fermenters. Journal of Biotechnology 70, 313-321. 
[10] Brennan, L., Owende, P., 2010. Biofuels from microalgae-A review of technologies for production, processing, and extractions of biofuels and coproducts. Renew. Sustain. Energy Rev. 14, 557-577.

[11] Cantrell KB, Ducey T, Ro KS, Hunt PG. Livestock waste-to-bioenergy generation opportunities. Bioresour Technol 2008; 99:7941-53.

[12] Chipman, L.; D. Podgorski, S. Green, J. Kostka, W. Cooper, M. Huettel, Decomposition of plankton-derived dissolved organic matter in permeable coastal sediments, Limnol.Oceanogr. 55 (2010) 857-871.

[13] Chisti, Y., 2007. Biodiesel from microalgae. Biotechnology Advances 25, 294-306.

[14] Christenson L, Sims R. Production and harvesting of microalgae for wastewater treatment, biofuels, and bioproducts. Biotechnol Adv 2011; 29:686702.

[15] Danquah MK, AngL, Uduman N, Moheimani N, Forde GM. Dewatering of micro algal culture for biodiesel production: exploring polymer flocculation and tangential flow filtration. J Chem Technol Biotechnol 2009; 84:1078-83.

[16] Danquah MK,GladmanB, MoheimaniN, FordeGM. Micro algal growth characteristics and subsequent influence on dewatering efficiency. Chem Eng J 2009; 151:73-8. [23]

[17] Davis, Ryan; Andy Aden, Philip T. Pienkos. Techno-economic analysis of autotrophic microalgae for fuel production. Applied Energy 88 (2011) 3524-3531.

[18] Dote, Y.; S. Sawayama, S. Inoue, T. Minowa, S.-Y. Yokoyama, Recovery of liquid fuel from hydrocarbon-rich microalgae by thermochemical liquefaction, Fuel 73 (1994) 1855-1857. 
[19] Doucha, J., Livansky, K., 2006. Productivity, $\mathrm{CO}_{2} / \mathrm{O}_{2}$ exchange and hydraulics in outdoor open high density microalgal (Chlorella sp.) photobioreactors operated in a Middle and Southern European climate. J. Appl. Phycol. 18, 811-826.

[20] Doucha, J., Livansky, K., 2009. Outdoor open thin-layer microalgal photobioreactor: potential productivity. J. Appl. Phycol. 21, 111-117.

[21] Doucha, J.; K. Livansky. Influence of processing parameters on disintegration of Chlorella cells in various types of homogenizers, Appl. Microbiol. Biotechnol. 81 (2008) 431-440.

[22] Draaisma, R.B.,Wijffels, R.H., Slegers, P.M., Brentner, L.B., Roy, A., Barbosa, M.J., 2013. Food Commodities from microalgae. Curr. Opin. Biotechnol. 24, 169-177

[23] Edgar, Thomas F.; Himmelblau, David M. 2001. Optimization of Chemical Processes. $2^{\text {nd }}$ ed. pp. 101. McGraw-Hill, New York.

[24] El-Halwagi, Mahmoud M. 2012. Sustainable Design through Process Integration: Fundamentals and Applications to Industrial Pollution Prevention, Conservation, and Profitability Enhancement. Pg, 55. Elsevier Inc.

[25] Fleurence, J.; The enzymatic degradation of algal cell walls: a useful approach for improving protein accessibility? J. Appl. Phycol. 11 (1999) 313-314.

[26] Furuki, T.; S. Maeda, S. Imajo, T. Hiroi, T. Amaya, T. Hirokawa, et al., Rapid and selective extraction of phycocyanin from Spirulina platensis with ultrasonic cell disruption, J. Appl.Phycol. 15 (2003) 319-324.

[27] Gao, L.; L. Zhang, J. Hou, Q. Wei, F. Fu, H. Shao, Decomposition of macroalgal blooms influences phosphorus release from the sediments and implications for coastal restoration in Swan Lake, Shandong, China, Ecol. Eng. 60 (2013)19-28. 
[28] Garcia-Moscosoa, Jose Luis; Wassim Obeidb, Sandeep Kumara, Patrick G. Hatcherba. Flash hydrolysis of microalgae (Scenedesmus sp.) for protein extractionand production of biofuels intermediates. J. of Supercritical Fluids 82 (2013) 183- 190.

[29] Gerde, J.A.; M. Montalbo-Lomboy, L. Yao, D. Grewell, T.Wang, Evaluation of microalga cell disruption by ultrasonic treatment, Bioresour. Technol. 125 (2012) 175-181.

[30] Gouveia, L.; A.C. Oliveira, Microalgae as a raw material for biofuels production, J. Ind. Microbiol. Biotechnol. 36 (2009) 269-274.

[31] Griffiths, M.J., Harrison, S.T.L., 2009. Lipid productivity as a key characteristic for choosing algal species for biodiesel production. Journal of Applied Phycology 21, 493-507.

[32] Grima, E.M., et al., 2003. Recovery of microalgal biomass and metabolites: process options and economics. Biotechnology Advances 20, 491-515.

[33] Hase, R., Oikawa, H., Sasao, C., Morita, M.,Watanabe, Y., 2000. Photosynthetic production of microalgal biomass in a raceway system under greenhouse conditions in Sendai City. J. Biosci. Bioeng. 89, 157-163.

[34] Hindersin, S., Leupold, M., Kerner, M., Hanelt, D., 2013. Irradiance optimization of outdoor microalgal cultures using solar tracked photobioreactors. Bioprocess Biosyst. Eng. 36, 345-355.

[35] Holtermann, Timm; Reinhard Madlener. Assessment of the technological development and economic potential of photobioreactors. J. Applied Energy 88 (2011) 1906-1919.

http://www.energybiosciencesinstitute.org/sites/default/files/media/AlgaeRepo rtFINAL.pdf [Accessed September 20, 2015]. 
[36] Jose L. Garcia-Moscoso, Ali Teymouri, and Sandeep Kumar. 2015. Kinetics of Peptides and Arginine Production from Microalgae (Scenedesmus sp.) by Flash Hydrolysis. pubs.acs.org/IECR.

[37] Katrina, L.;Christiansen,; D. Raj,Raman; Robert.P.Anex. Predicting Cost Growth and Performance of First-generation Algal Production Systems. J. Energy Policy 51 (2012) 382-391.

[38] Ketheesan, B.; N. Nirmalakhandan Development of a new airlift-driven raceway reactor for algal cultivation. J. Appl Energy 2011; 88:3370-6.

[39] Kumar, Kanhaiya; Sanjiv K. Mishra; Anupama Shrivastav; Min S. Park; Ji-WonYang. Recent trends in the mass cultivation of algae in raceway ponds. Renewable and Sustainable Energy Reviews 51 (2015) 875-885.

[40] Lam, M.K., Lee, K.T., 2012. Microalgae biofuels: a critical review of issues, problems and the way forward. Biotechnol. Adv. 30, 673-690.

[41] Lam, MK; Lee KT, Mohamed AR. Current status and challenges on microalgae based carbon capture. Int J Greenhouse Gas Control 2012; 10:456-69.

[42] Lardon, L., et al., 2009. Life-cycle assessment of biodiesel production from microalgae. Environmental Science \& Technology 43 (17), 6475-6481.

[43] Lee, J.Y.; C. Yoo; S.Y. Jun, C.Y. Ahn, H.M. Oh, Comparison of several methods for effective lipid extraction from microalgae, Bioresour. Technol. 101 (Suppl. 1) (2010) S75-S77.

[44] Lee, Yuan-Kun; Microalgal mass culture systems and methods: their limitation and potential, J. Appl. Phycol. 13 (4) (2001) 307-315.

[45] Li, Shuwen; Shengjun Luo; Rongbo Guo. Efficiency of $\mathrm{CO}_{2}$ fixation by microalgae in a closed raceway pond. J. Bioresource Technology 136 (2013) 267272. 
[46] Lundquist, Tryg; Woertz, Ian; Nigel Quinn, John Benemann. A Realistic Technology and Engineering Assessment of Algae Biofuel Production, Energy Biosciences Institute Report 2010.

[47] Mendes-Pinto, M.M.; M.F.J. Raposo, J. Bowen, A.J. Young, R. Morais, Evaluation of different cell disruption processes on encysted cells of Haematococcus pluvialis: effects on astaxanthin recovery and implications for bioavailability, J. Appl. Phycol. 13(2001) 19-24. Jubeau , S.; L.

[48] Minowa , T.; S.-Y.Yokoyama,M. Kishimoto, T. Okakura, Oil production from algal cells of Dunaliella tertiolecta by direct thermochemical liquefaction, Fuel 74 (1995) 1735-1738.

[49] Moheimani, N.R., Borowitzka, M.A., 2006.The long-term culture of the coccolitho-phorid Pleurochrysis carterae (Haptophyta) in outdoor raceway ponds. Journal of Applied Phycology 18,703-712.

[50] Molina, Grima E, Belarbi EH, Acién Fernández FG, Robles Medina A, Chisti Y. Recovery of micro algal biomass and metabolites: process options and economics. Biotechnol Adv 2003; 20:491-515.

[51] Morita, M., Watanabe, Y., Saiki, H., 2002. Photosynthetic productivity of conical helical tubular photobioreactor incorporating Chlorella sorokiniana under field conditions. Biotechnol. Bioeng. 77, 155-162.

[52] Navarro da Silva, Alexandre; Ronaldo Perez, Valéria Paula Rodrigues Minim, Danielle Dias Sant'Anna Martins, Luis Antônio Minim. Integrated Production of Whey Protein Concentrate and Lactose Derivatives: What is the best combination? J. Food Research International 73 (2015) 62-74.

[53] Patil V, Tran K-Q, Giselrød HR. Towards sustainable production of biofuels from microalgae. Int J Mol Sci 2008;9: 1188-95 
[54] Qin, Shan; Guo-Xiang Liu a; Zheng-Yu Hu. 2008. The accumulation and metabolism of astaxanthin in Scenedesmus obliquus (Chlorophyceae). Process Biochemistry 43 (2008) 795-802.

[55] Quinn, Jason C., Ryan Davis. 2014. The Potentials and Challenges of Algae Based Biofuels: A review of the Techno-economic, Life Cycle, and Resource Assessment Modeling. Bioresource Technology 184 (2015) 444-452.

[56] Rawat I, Ranjith Kumar R, Mutanda T, Bux F. Dual role of microalgae: phyco-remediation of domestic wastewater and biomass production for sustainable biofuels production. J. Appl Energy 2011; 88:3411-24.

[57] Richardson, James W.; Myriah D. Johnson; Xuezhi Zhang; Peter Zemke; Wei Chen; Qiang Hu. 2014. A financial assessment of two alternative cultivation systems and their contributions to algae biofuel economic viability.J. Algal Research 4, 96-104.

[58] Rios, S.D., Torres, C.M., Torras, C., Salvado, J., Mateo-Sanz, J.M., Jimenez, L., 2013. Microalgae-based biodiesel: economic analysis of downstream process realistic scenarios. Bioresour. Technol. 136, 617-625.

[59] Rogers, Jonathan N; Julian N. Rosenberg; Bernardo J. Guzman; Victor H. Oh; Luz Elena Mimbela; Abbas Ghassemi; Michael J. Betenbaugh; George A. Oyler; Marc D. Donohue. A Critical Analysis of Paddlewheel-driven Raceway Ponds for Algal Biofuel Production at Commercial Scales. J. Algal Research 4 (2014) 76-88.

[60] Sánchez-Camargo, Andrea del Pilar; Lidia Montero; Valérie StigerPouvreau, Anaëlle Tanniou Sari, Y.W.; M.E. Bruins, J.P.M. Sanders, Enzyme assisted protein extraction from rapeseed, soybean, and microalgae meals, Ind. Crop. Prod. 43 (2013) 78-83. Appl. Energy 106, 262-274. 
[61] Schlesinger A, Eisenstadt D, Bar-Gil A, Carmely H, Einbinder S, Gressel J. Inexpensive non-toxic flocculation of micro algae contradicts theories; overcoming a major hurdle to bulk algal production. Biotechnol Adv 2012; 30: 1023-30.

[62] Sharp, J.H.; Estuarine oxygen dynamics: what can we learn about hypoxia from long-time records in the Delaware Estuary? Limnol. Oceanogr. 55 (2010)535-548.

[63] Shen, Q; C. Liu, Q. Zhou, J. Shang, L. Zhang, C. Fan, Effects of physical and chemical characteristics of surface sediments in the formation of shallow lake algae-induced black bloom, J. Environ. Sci. China 25 (2013) 2353-2360.

[64] Slade, Raphael; Ausilio Bauen. Micro-algae cultivation for biofuels: Cost, energy balance, environmental impacts and future prospects. J. Biomass and Bioenergy 53 (2013) 29-38.

[65] Sun, Q.; J. Chen, H. Zhang, S. Ding, Z. Li, P.N. Williams, H. Cheng, C. Han, L. Wu,C. Zhang, Improved diffusive gradients in thin films (DGT) measurement of total dissolved inorganic arsenic in waters and soils using a hydrous zirconium oxide binding layer, Anal. Chem. 86 (2014) 3060-3067.

[66] Tan, Chung Hong; Pau Loke Showa,b, Jo-Shu Chang c,d,e, Tau Chuan Ling f, John Chi-Wei Lan. Novel approaches of producing bioenergies from microalgae: A recent review. Biotechnology Advances 33 (2015) 1219-1227.

[67] Taylor, B., Xiao, N., Sikorski, J., Yong,M., Harris, T., Helme, T., Smallbone, A., Bhave, A., Kraft, M., 2013. Techno-economic assessment of carbon-negative algal biodiesel for transport. J. Applied Energy.

[68] Tibbetts, Sean M.; Joyce E. Milley; Santosh P. Lall. 2015. Chemical Composition and Nutritional Properties of Freshwater and Marine Microalgal 
Biomass Cultured in Photobioreactors. Journal of Applied Phycology.Volume 27, Issue 3, pp 1109-1119.

[69] Tsukahara K, Sawayama S. Liquid fuel production using microalgae. J Jpn Pet Inst 2005; 48: 251.

[70] Ursu, Alina-Violeta; Alain Marcati; Thierry Sayd; Véronique SanteLhoutellier; Gholamreza Djelveh; Philippe Michaud. 2014. Extraction, Fractionation and Functional Properties of Proteins from the Microalgae Chlorella Vulgaris. Bioresource Technology 157 (2014) 134-139.

[71] Valdez, Peter J.; Savage, Phillip E. A reaction network for the hydrothermal liquefaction of Nannochloropsis sp. Algal Research 2 (2013) 416425.

[72] Valdez, Peter J.; Vincent J. Tocco; Phillip E. Savage. A general kinetic model for the hydrothermal liquefaction of microalgae. Bioresource Technology 163 (2014) 123-127.

[73] Ward, A.J; D.M. Lewis, F.B. Green. Anaerobic digestion of algae biomass: A review. Algal Research 5 (2014) 204-214.

[74] Weissman J. C, Goebel RP, Benemann JR. Photobioreactor design: mixing, carbon utilization, and oxygen accumulation.J. Biotechnol Bioeng 1988;31 (4):336-44.

[75] Weyer, K.M., Bush, D.R., Darzins, A., Willson, B.D., 2010. Theoretical maximum algal oil Production. J. Bioenergy Res. 3, 204-213.

[76] Wijffels, R.H, Barbosa MJ. An outlook on microalgal biofuels.Science 2010; 329(5993):796-9. 
[77] Yang Y. F, Feng CP, Inamori Y, Maekawa T. Analysis of energy conversion characteristics in liquefaction of algae. Resour Conserv Recycl 2004; 43:21-33.

[78] Zheng, H.; J. Yin, Z. Gao, H. Huang, X. Ji, C. Dou, Disruption of Chlorella vulgaris cells for the release of biodiesel-producing lipids: a comparison of grinding, ultrasonication, bead milling, enzymatic lysis, and microwaves, Appl. Biochem. Biotechnol. 164 (2011) 1215-1224.

[79] Zhu, G. M.; L. Zhu, X. Zhao, Y. Yao, G. Zhang, B. Qin Gao, Influence of algal bloom degradation on nutrient release at the sediment-water interface in Lake Taihu, China, Environ. Sci. Pollut. Res. Int. 20 (2013) 1803-1811. 


\section{APPENDIX}

\section{A1. Calculation of Direct Cost (DC)}

Piping $(\mathrm{A})=0.35 \times \mathrm{PC}$

Instrumentation $(\mathrm{B})=0.4 \times \mathrm{PC}$

Insulation $(\mathrm{C})=0.03 \times \mathrm{PC}$

Electricals Facilities (D) $=0.1 \times$ PC

Buildings (E) $=0.45 \times$ PC

Yard Improvement $(F)=0.15 \times$ PC

Auxiliary $(\mathrm{G})=0.4 \times \mathrm{PC}$

Installation $=$ Installation of listed equipment + Installation of Unlisted (overlooked)

equipment.

Unlisted equipment installation cost $=0.5 \mathrm{x}$ unlisted equipment cost

$\Rightarrow \mathrm{DC}=\mathrm{PC}+$ Installation $+\mathrm{A}+\mathrm{B}+\mathrm{C}+\mathrm{D}+\mathrm{E}+\mathrm{F}+\mathrm{G}$

\section{A2. Indirect Cost (IC) is calculated as follows:}

Engineering $(\mathrm{H})=0.25 \times \mathrm{DC}$

Construction $(\mathrm{I})=0.35 \times \mathrm{DC}$

\section{A3. Other Cost (OC) is calculated as follows:}

Contractor's fee $=0.05(\mathrm{DC}+\mathrm{IC})$

Contingency $=0.1(\mathrm{DC}+\mathrm{IC})$ 


\section{A4. Financial Calculations}

\section{Inputs}

Tax rate

$40 \%$

Interest rate

$10 \%$

Project life

$15 \mathrm{yr}$

\section{Cash flow}

Land in zero years

$30 \%$ of the FCI in $1^{\text {st }} \mathrm{yr}$

$40 \%$ of the FCI in 2nd yr

$30 \%$ of the FCI In the 3rd yr

Annual COP, \$M

145

\section{Revenue}

Price of protein, \$/ton

Unknown (y)

Total protein produced, ton/yr 50688

Energy, \$M

Annual Revenue

$$
\begin{aligned}
& =50688 \mathrm{y}+13.31 \times 10^{6}-145^{*} 10^{6} \\
= & \left(50688 \mathrm{y}-131.69 * 10^{6}\right) *(1-\text { Tax rate }) \\
= & 30412.8 \mathrm{y}-79.014 \mathrm{x} 10^{6} \\
= & (0.030413 \mathrm{y}-79.014) * 10^{6}
\end{aligned}
$$


Table A1 Calculation of minimum protein concentrate

\begin{tabular}{|c|c|c|c|c|}
\hline $\begin{array}{l}\text { End of } \\
\text { year } \\
n\end{array}$ & $\begin{array}{c}\text { Annual } \\
\text { (nondiscounted } \\
\text { Cash Flow)/\$ } \\
\text { Milllion } \\
\end{array}$ & $\begin{array}{l}\text { Discount } \\
\text { factor } \\
\frac{1}{(1+i)^{n}}\end{array}$ & $\begin{array}{l}\text { Discounted cash } \\
\text { flow in \$ MM }\end{array}$ & $\begin{array}{c}\text { Cumulated } \\
\text { discounted } \\
\text { Cash flow (\$MM) }\end{array}$ \\
\hline 0 & -21.5 & 1.000 & -21.5 & -21.5 \\
\hline 1 & -79.05 & 0.909 & -71.8644 & -93.4 \\
\hline 2 & -105.4 & 0.826 & -87.1026 & -180.5 \\
\hline 3 & -79.05 & 0.751 & -59.3903 & -239.9 \\
\hline 4 & $(0.0304 y-79.0)$ & 0.683 & $0.0208 y-53.96$ & $0.0208 y-293.81$ \\
\hline 5 & $(0.0304 y-79.0)$ & 0.621 & $0.0189 y-49.05$ & $0.0396 y-342.87$ \\
\hline 6 & $(0.0304 y-79.0)$ & 0.564 & $0.0172 y-44.60$ & $0.0568 y-387.46$ \\
\hline 7 & $(0.0304 y-79.0)$ & 0.513 & $0.0156 y-40.54$ & $0.0724 y-428.00$ \\
\hline 8 & $(0.0304 y-79.0)$ & 0.467 & $0.0142 y-36.85$ & $0.0866 y-464.86$ \\
\hline 9 & $(0.0304 y-79.0)$ & 0.424 & $0.0129 y-33.50$ & $0.0995 y-498.36$ \\
\hline 10 & $(0.0304 y-79.0)$ & 0.386 & $0.0117 y-30.45$ & $0.1112 y-528.82$ \\
\hline 11 & $(0.0304 y-79.0)$ & 0.350 & $0.0107 y-27.69$ & $0.1218 \mathrm{y}-556.50$ \\
\hline 12 & $(0.0304 y-79.0)$ & 0.319 & $0.0097 y-25.17$ & $0.1315 y-581.67$ \\
\hline 13 & $(0.0304 y-79.0)$ & 0.290 & $0.0088 y-22.89$ & $0.1403 y-604.56$ \\
\hline 14 & $(0.0304 y-79.0)$ & 0.263 & $0.0080 y-20.80$ & $0.1483 y-625.36$ \\
\hline 15 & $(0.0304 y-79.0)$ & 0.239 & $0.0073 y-18.91$ & $0.1556 y-644.27$ \\
\hline
\end{tabular}

The value of y can be solved by equating the sum of discounted cash flow, NPV, to zero gives y to be $\$ 4.14 / \mathrm{kg}$. i.e. the minimum price of protein concentrate. 
Table A2 Simulation based on production of different capacities

\begin{tabular}{|c|c|c|c|c|c|c|c|c|c|c|c|c|}
\hline Algae & Protein & FCI & AOC, & $\mathrm{AC}$ & Power (gen) & Power(used) & Water & Unit Cost & Price, & $\mathrm{CO}_{2}$ Captured & Land & Natural \\
\hline MT/day & MT/day & $\$ M$ & $\$ M$ & $\$ M$ & MW & MW & $\mathrm{MT} / \mathrm{h}$ & $\$ / \mathrm{kg}$ & $\$ / k g$ & $\mathrm{MT} / \mathrm{h}$ & acres & Gas MT/h \\
\hline 105 & 60 & 110 & 64 & 78 & 9 & 7 & 250 & 3.37 & 4.76 & 10 & 2692 & 5 \\
\hline 168 & 78 & 138 & 80 & 98 & 13 & 10 & 344 & 3.24 & 4.57 & 13 & 3544 & 7 \\
\hline 336 & 161 & 264 & 146 & 180 & 21 & 19 & 649 & 2.86 & 4.13 & 27 & 7177 & 12 \\
\hline 420 & 202 & 325 & 177 & 220 & 26 & 24 & 802 & 2.8 & 4.05 & 33 & 8971 & 14 \\
\hline 504 & 239 & 385 & 209 & 259 & 30 & 29 & 952 & 2.77 & 4.04 & 40 & 10765 & 17 \\
\hline 588 & 285 & 444 & 240 & 299 & 35 & 34 & 1105 & 2.71 & 3.95 & 46 & 12559 & 19 \\
\hline 694 & 335 & 523 & 281 & 350 & 41 & 40 & 1294 & 2.69 & 3.93 & 55 & 14802 & 22 \\
\hline 778 & 373 & 583 & 313 & 390 & 46 & 45 & 1454 & 2.67 & 3.89 & 61 & 16596 & 25 \\
\hline 883 & 423 & 658 & 353 & 440 & 52 & 51 & 1642 & 2.65 & 3.87 & 70 & 18839 & 28 \\
\hline 970 & 466 & 723 & 386 & 481 & 57 & 55 & 1800 & 2.65 & 3.87 & 76 & 20633 & 31 \\
\hline 1051 & 504 & 784 & 419 & 522 & 63 & 60 & 1960 & 2.65 & 3.87 & 83 & 22427 & 34 \\
\hline 1157 & 557 & 857 & 458 & 571 & 69 & 66 & 2148 & 2.62 & 3.83 & 91 & 24669 & 37 \\
\hline
\end{tabular}


Table A3. Prices of Protein Concentrates on the market

\begin{tabular}{|c|c|c|c|c|c|}
\hline $\begin{array}{l}\text { Protein } \\
\text { Type }\end{array}$ & Quantity & $\begin{array}{r}\text { Price, } \\
\$\end{array}$ & $\begin{array}{r}\text { Price } \\
\$ / \mathrm{kg}\end{array}$ & $\begin{array}{l}\% \\
\text { protein }\end{array}$ & Market \\
\hline Whey Protein Isolate powder & $5 \mathrm{lb}$ & 57 & 25.11 & 90 & Amazon \\
\hline Soy Protein Isolate powder & $2 \mathrm{lb}$ & 23 & 25.33 & $>90$ & Amazon \\
\hline Fish Protein Powder & $1 \mathrm{~kg}$ & 35 & 35.00 & $>90$ & Alibaba \\
\hline Rice Protein Powder & 1 ton & 3800 & 3.80 & $>80$ & Alibaba \\
\hline Spirulina powder (algae) & $1 \mathrm{~kg}$ & 10 & 10.00 & 60 & Alibaba \\
\hline Sacha Inchi Powder (organic) & $1 \mathrm{~kg}$ & 8.5 & 8.50 & 60 & Alibaba \\
\hline
\end{tabular}

Source: Alibaba Group Holding Limited; Amazon.com, Inc. 


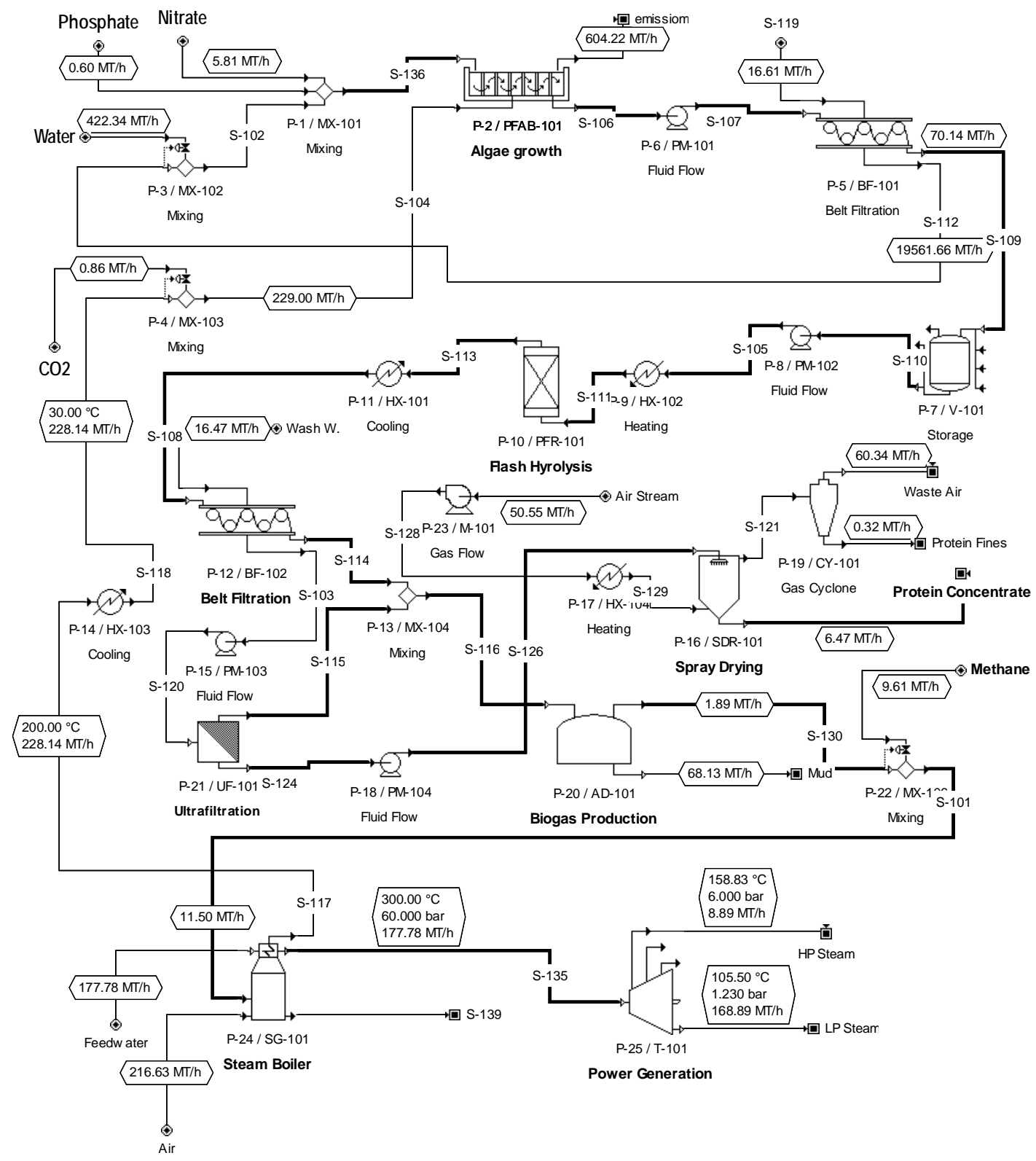

Figure A1. Production of 95 wt.\% protein concentrate via flash hydrolysis modelled by SuperPro Designer v.9. 


\section{VITA}

Alexander Asiedu is a graduate student from the Department of Civil and Environmental Engineering at Old Dominion University, Virginia.

He holds BSc. Metallurgical Engineering and MSc. Chemical Engineering both from Kwame Nkrumah University of Science and Technology, Ghana, in 2002 and 2008 respectively. He is currently pursuing Ph.D. Environmental Engineering at Old Dominion University.

He has eight-year professional experience as a plant metallurgist at Sian Goldfields in Ghana. His area of specialization is process design, economic analysis, and life cycle analysis.

The word processor for this thesis was Microsoft Word. 